\title{
PALATABILITY AND CHEMICAL DEFENSE OF MARINE INVERTEBRATE LARVAE ${ }^{1}$
}

\author{
Niels Lindquist AND MARK E. HAY \\ University of North Carolina at Chapel Hill, Institute of Marine Sciences, \\ Morehead City, North Carolina 28557 USA
}

\begin{abstract}
Risk of larval mortality is a critical component of models and debates concerning the ecology and evolution of the differing reproductive characteristics exhibited by marine invertebrates. In these discussions, predation often is assumed to be a major source of larval mortality. Despite limited empirical support, most marine larvae are thought to be palatable and broadly susceptible to generalist predators. Previous studies of larvalplanktivore interactions have focused primarily on larvae that typically feed, grow, and develop for weeks to months in the plankton. Such planktotrophic species commonly produce large numbers of small larvae that disperse over vast distances. In contrast, the nonfeeding lecithotrophic larvae from sessile invertebrates that brood are often large and conspicuous, lack morphological defenses, and have limited dispersal distances because they typically are competent to settle minutes to hours after spawning. Interactions between lecithotrophic larvae and consumers are not well studied. This has limited the ability of previous authors to test broad generalities about marine larvae.

We show that brooded larvae of Caribbean sponges (11 species) and gorgonians (three species) as well as brooded larvae of temperate hydroids (two species) and a bryozoan are unpalatable to co-occurring fishes. In contrast, brooded larvae of temperate ascidians (three species), a temperate sponge, and Caribbean hard corals (three species) are readily consumed by fishes, as are larvae from four of six species of synchronous broadcast-spawning gorgonians from the Florida Keys. Frequencies of survivorship for larvae attacked and rejected by fishes were high and statistically indistinguishable from frequencies for unattacked control larvae. Frequency of metamorphosis (when it occurred) of rejected larvae never differed significantly from that of unattacked control larvae. Assays testing for larval vs. adult chemical defenses for five species with distasteful larvae showed that larvae of all five species were chemically distasteful to fishes, whereas only three of five adult extracts deterred fish feeding. A comparison of larval palatability among chemically rich taxa showed that brooded larvae were significantly more likely to be unpalatable ( $86 \%$ of the species tested) than larvae of broadcasters (33\%), and that palatable larvae were rarely released during the day $(23 \%)$ while unpalatable larvae usually were ( $89 \%)$. Additionally, the frequency of bright coloration was high (60\%) for unpalatable larvae and low (0\%) for palatable larvae, suggesting that unpalatable larvae often may be aposematically colored. Results of this broad survey cast doubt on the widely accepted notion that virtually all marine larvae are suitable prey for most generalized planktivores.

Among species that do not chemically or physically protect larvae against fishes, selection appears to favor the release of larvae at night, or the production of smaller more numerous offspring that grow and develop at sea as a way of escaping consumer-rich benthic habitats. Because distasteful larvae are not similarly constrained, distasteful species should exhibit reproductive and larval characteristics selected more by the fitness-related consequences of larval development mode and dispersal distance than by the necessity of avoiding benthic predators. Production of large larvae and retention of offspring in parental habitats that have proved to be suitable for growth and reproduction have both been proposed as advantageous, but these advantages often were assumed to be offset by losses due to increased larval apparency to fishes. This assumed trade-off is not mandatory because larvae can be defended chemically. Distasteful larvae tend to be conspicuous, localized dispersers that can co-occur with benthic fishes, and yet not be consumed.
\end{abstract}

Key words: chemical defenses; complex life cycles; invertebrate larval defenses; larval palatability; life history patterns.

\section{INTRODUCTION}

Most marine invertebrates have complex life cycles consisting of a planktonic larval stage that settles to

\footnotetext{
${ }^{1}$ Manuscript received 12 December 1994; revised and accepted 12 December 1995; final version received 2 February 1996.
}

the benthos and metamorphoses into a more sedentary (often sessile) form. Some species produce large numbers of very small larvae that feed (=planktotrophy), grow, and develop through several stages in the plankton before becoming competent to settle and metamorphose. Larvae with planktotrophic development may spend months in the plankton and disperse over 
vast distances. Other species produce a smaller number of larger, nonfeeding larvae that use yolk as a source of nutrition (=lecithotrophy). Larvae with lecithotrophic development often spend limited time in the plankton and disperse over shorter distances than planktotrophic larvae. Some lecithotrophs brood larvae to an advanced stage; these larvae may settle near their parents after only minutes in the plankton. Variation within each of these general reproductive modes is considerable, and other reproductive modes also occur among marine invertebrates (Thorson 1946, 1950, Mileikovsky 1971).

There is considerable debate about factors affecting the evolution of complex life cycles and types of larval development (Thorson 1946, 1950, Mileikovsky 1971, Vance 1973, Strathmann 1974, 1980, 1985, 1986, 1993, Underwood 1974, Pechenik 1979, Palmer and Strathmann 1981, Strathmann and Strathmann 1982, Grant 1983, Grahame and Branch 1985, Hines 1986, Jackson 1986, Rumrill 1990). Hypotheses and theoretical models focused on the evolution of life history patterns among marine invertebrates commonly weigh the risk of embryonic and larval mortality against reproductive and larval characteristics that may modify this risk (e.g., parental investment per embryo, brooding vs. free spawning, pelagic vs. benthic larval development, and - feeding vs. nonfeeding larvae; Thorson 1950, Vance 1973, Pechenik 1979, Strathmann 1982, 1985, 1986, Grant 1983, Rumrill 1990). Predation on larvae is usually assumed to be the most substantial cause of presettlement mortality (Thorson 1946, 1950, Young and Chia 1987), although advection away from suitable benthic habitats can also result in considerable larval mortality (Roughgarden et al. 1988). Important larval predators include fishes and invertebrates (Young and Chia 1987), but only fishes have been directly shown to affect the distribution and abundance of invertebrates by severely reducing larval densities (Gaines and Roughgarden 1987, Olson and McPherson 1987). Although very few studies have directly evaluated larval susceptibility to predators, most models evaluating larval development assume that larvae of most species are palatable and broadly susceptible to generalist consumers.

Pelagic environments are considered safer than benthic environments for unprotected embryos and larvae (Pechenik 1979, Highsmith 1985, Strathmann 1985, 1986), but retention of offspring in parental habitats may provide selective advantages over having larvae widely dispersed by ocean currents (Jackson 1986). Thus, retention of palatable larvae in adult habitats that have proven to be adequate for growth and reproduction could entail heavy losses to predators, but larvae that escape these benthic predators by developing in the plankton risk never being returned to habitats that are suitable for settlement and growth. If these assumed problems and trade-offs generally apply, then species with palatable larvae may often produce larvae that grow and develop in the plankton where they escape benthic predators. If most of these larvae never reach suitable benthic habitats, then these species may benefit from producing many small larvae with minimal investment in each. In contrast, if a species can defend larvae from most consumers, then these larvae could be retained in predator-rich benthic habitats near adults, thus, avoiding "wastage" in the plankton. Differences between these types of larvae in the time needed for development before settlement, and thus in the distance they disperse, can have important implications for genetic variation within and among populations (Burton 1986, Grosberg and Quinn 1986, Mitton et al. 1989), adaptations to local conditions (Jackson 1986), and rates of speciation and extinction (Jablonski and Lutz 1983, Jablonski 1986).

The wealth of citations provided above indicate the broad-scale importance of, and interest in, understanding the ecology and evolution of complex life cycles and modes of larval development, however, our ability to address these issues rigorously is severely compromised by the paucity of ecologically relevant information on the larval stages of marine organisms. Previous theoretical investigations of invertebrate life histories have assumed that most larvae are poorly defended against consumers and, therefore, that virtually all larvae are palatable.

Although predation on larvae can affect the demography of some marine invertebrates (Gaines and Roughgarden 1987, Olson and McPherson 1987, Stoner 1990), a broad understanding of larval-planktivore interactions is lacking, especially for lecithotrophic larvae. Most published studies have focused on planktotrophic species (Young and Chia 1987) and previous investigators (Hines 1986, Strathmann 1986, Young and Chia 1987) noted that it would be difficult to understand processes affecting the evolution of life history patterns among marine invertebrates without better comparative data for planktotrophic vs. lecithotrophic larvae. Additional data on lecithotrophic larvae would permit a more thorough contrast of planktotrophs with lecithotrophs and a better informed evaluation of processes proposed to be crucial in the evolution of life history patterns in marine invertebrates.

Adults of sessile marine invertebrates that lack physical defenses against predators and that grow on exposed substrates in predator-rich communities (e.g., reef sponges, soft corals, gorgonians, and colonial ascidians) are commonly defended by secondary metabolites (Paul 1992, Pawlik 1993). Many of these softbodied sessile species release lecithotrophic larvae that are large, conspicuous, and lacking apparent morphological defenses against consumers. These larvae should profit from being chemically distasteful. In contrast, both chemical defenses (Faulkner 1993 and previous reviews cited therein) and lecithotrophic larval development (Thorson 1946, Barnes 1987) appear less common among mobile and aclonal taxa. 
How chemical defense of eggs and larvae could alter the viability of various life history traits has not been investigated, but chemical defenses have been reported in asteroid eggs (Lucas et al. 1979, McClintock and Vernon 1990), ascidian larvae (Young and Bingham 1987, Lindquist et al. 1992), and the egg masses of a nudibranch (Pawlik et al. 1988). Because chemically distasteful larvae have less need to avoid predators, the life history characteristics of species with defended larvae should be affected more by the fitness-related consequences of development mode and dispersal than by the assumed advantages of avoiding benthic consumers by entering the plankton. Thus, studies focused on species with chemically unpalatable larval stages could offer insights into the importance of factors other than consumers in affecting the evolution of life history patterns.

To determine whether the palatability of lecithotrophic larvae from diverse sessile invertebrates varies, and how larval palatability may relate to other life history traits, we examined larval palatability to co-occurring fishes using larvae from sponges (12 species), gorgonians (nine species), corals (three species), hydroids (two species), ascidians (three species), and a bryozoan (one species). We also determined survivorship of distasteful larvae after they were attacked and rejected by fishes. We used fishes as consumers because fishes have been shown to dramatically reduce larval abundance in both tropical and temperate locations (Gaines and Roughgarden 1987, Olson and McPherson 1987). Additional assays using corals and anemones as larval predators will appear as a separate study (Lindquist 1996). Results of this study with invertebrate planktivores indicate that patterns of larval palatability to fishes and invertebrates are similar. Results of assays from the present study were interpreted with respect to what is known about the reproductive mode, spawning behavior, and larval characteristics of the species studied. To determine whether distasteful larvae were chemically defended, and to compare larval with adult chemical defenses, we examined the palatability of chemical extracts from larvae and adults of five species with distasteful larvae. Our emphasis on species with lecithotrophic larvae provides data that can be compared with published data on planktotrophic larvae to produce a more balanced view of larval susceptibilities to, and possible defensive adaptations against, predators.

\section{METHODS}

\section{Collection sites and organisms}

Most tropical invertebrates were collected from two barrier reefs (Conch Reef and Pickles Reef) and a patch reef (Three Sisters) near Key Largo, Florida. One sponge, Tedania ignis, and its larvae were collected from Jewfish Creek in the mangrove swamps near Key Largo. Additional collection sites for Caribbean reef sponges were Little San Salvador Island and Chub Cay in the Bahamas. All temperate invertebrates came from two collection sites in North Carolina. At Radio Island Jetty near Beaufort, North Carolina, we collected invertebrates from 2 to $5 \mathrm{~m}$ below mean low tide. The second collection site was a 17-19 m deep rock ledge located $8 \mathrm{~km}$ east of Wrightsville Beach, North Carolina. Both sites have dense populations of sponges, hydroids, bryozoans, and ascidians.

Appendix A contains information on invertebrate collection sites, depths, and times, and Appendix B presents information on larval collection methods. Physical descriptions of study animals can be found in the following references: Caribbean sponges-Zea (1987), Humann (1993a); Caribbean gorgoniansBayer (1961), Humann (1993b); Caribbean hard corals-Sterrer (1986), Humann (1993b); North Carolina invertebrates-Sterrer (1986) and Ruppert and Fox (1988).

For bioassays of larval palatability to tropical fishes, we chose the bluehead wrasse Thalassoma bifasciatum and the bicolor damselfish Stegastes partitus. These species are two of the more abundant small fishes on Caribbean reefs and are broad generalists that feed extensively on small benthic and planktonic prey (Feddern 1965, Randall 1967, Emery 1973). For larval predators from temperate North Carolina, we chose juvenile stages of the pinfish Lagodon rhomboides and of the fringed file fish Monocanthus ciliatus. Along the Carolina coast, juvenile stages of these two fishes occur abundantly in a wide variety of habitats during the spring and summer spawning season for many benthic invertebrates (Sutherland 1981). Their broad diets include invertebrate larvae (Darcy 1985; N. Lindquist, personal observation). Thalassoma and Stegastes were collected using hand nets in coral rubble fields behind Pickles Reef and at various shallow water reefs in the Bahamas. Juvenile Lagodon and Monocanthus were collected by seining seagrass beds near Morehead City, North Carolina.

During our investigations, we recorded data on larval size, larval color, diel timing of larval or gamete release, and whether larvae were brooded internally, brooded on adult surfaces, deposited externally in gelatinous masses, or the product of synchronous broadcast spawning. These data (Appendix C) were used in conjunction with results of the feeding assays to determine which reproductive and larval characteristics were commonly associated with unpalatable larvae.

Knowlton and Jackson (1994) argue that unrecognized sibling species may be common among coralreef invertebrates. In our study, an apparent example of this may be Pseudoplexaura porosa at Three Sisters Reef. One group of these animals produced white larvae in July 1993 that were unpalatable to fishes, while another group at this site produced tan larvae in August 1993 that were palatable to fishes (see Results). We designated these groups Pseudoplexaura-A and 
Pseudoplexaura-B, respectively. Additionally, we obtained larvae from both the encrusting and upright forms of the gorgonian Briareum asbestinum. Recent genetic evaluation of these two morphs suggests that they are separate species (Brazeau and Harvell 1994). We designated these Briareum-E (encrusting) and Briareum-U (upright).

\section{Assays of larval palatability}

All feeding assays with larvae of Caribbean invertebrates were conducted at either NOAA's National Undersea Research Center at Key Largo, Florida, or aboard the R/V Columbus Iselin at various sites in the Bahamas. Assays with larvae of temperate invertebrates were performed at the University of North Carolina's Institute of Marine Sciences in Morehead City, North Carolina.

To determine the palatability of invertebrate larvae, we placed groups of Thalassoma (2-4 fish per group) in separate aquaria and individual Stegastes, Lagodon, and Monocanthus in perforated plastic bowls (1 L) held in a shallow water table. Both systems were set up with flow-through seawater. Each aquarium or bowl served as a single replicate. Each assay was run using 5-20 replicates. Fishes were fed live brine shrimp or freezedried krill each morning and each afternoon. Fishes were not starved prior to our assays. This ensured that their motivation to feed on any food or larva offered would not be unnaturally high. Larval palatability assays began at least $1 \mathrm{~h}$ after either of these major feedings.

Assays were performed by first offering each fish (or group of fish) a live brine shrimp (=palatable control). If the brine shrimp was eaten, we offered that replicate a single larva. Initially, we offered each replicate a second brine shrimp if the larva was rejected to determine if the fish remained willing to feed. Because the second brine shrimp was virtually always eaten, we discontinued this practice so as to allow more time for additional feeding assays. All larvae used in feeding assays were alive and motile. Any fish that did not eat the brine shrimp was not used to assess larval palatability. This practice produced variable numbers of replicates among assays and always set our consumption of control food at $100 \%$. After offering a larva to the fish, we recorded whether the larva was attacked, and if the larva was consumed or rejected after being taken into a fish's mouth. Unpalatable larvae were often repeatedly tasted and rejected, commonly 3-6 times and in some cases as many as 13 times, before the fish stopped the attack. To analyze palatability results, we used Fisher's exact test to compare statistically the number of replicates consuming brine shrimp with the number consuming larvae. If a larva was not tasted by the fish, that trial was excluded from our statistical analysis. Our analysis thus examined whether larvae were rejected once tasted, not whether they were avoided without being sampled. Although visual recognition and avoidance of unpalatable larvae may be an ecologically important interaction between larvae and fishes, uncertainties about how fish view larval prey in natural waters and in our experimental containers discouraged our examination of this behavior.

\section{Determining levels of larval survivorship after rejection by a predator}

To determine whether a fish attack diminished the survivorship or hindered eventual metamorphosis of distasteful larvae, we recovered larvae that fish attacked but rejected. Each recovered larva was placed in a separate covered polystyrene petri dish with $5 \mathrm{~mL}$ of seawater. Controls for these survivorship assays were larvae that had been held in the same containers as larvae used in the feeding assay but never offered to fish. In general, each recovered larva was matched by an unattacked control larva that was treated in a manner identical to rejected larvae. We scored larval survival 1-6 d after the feeding assay. Only visibly decomposing larvae were scored as dead; all others were regarded as alive. If $>80 \%$ of the larvae were consumed in an assay, the survivorship of rejected larvae was not determined because surviving larvae were too few to provide reliable sample sizes.

Even though a larva may survive an attack, it might be rendered incapable of settlement and metamorphosis. To investigate this possibility, we recorded the frequency of metamorphosis among rejected and control larvae. Differences in survival and metamorphic success of rejected and control larvae were evaluated using Fisher's exact test. For four assays, the limited number of available larvae prevented setting up unattacked controls. In one assay, the delicate larvae of the sponge Mycale laxissima were commonly torn apart during attacks by Thalassoma, which did not appear to consume larval fragments (see Results). We recovered most of the larger Mycale fragments and monitored their survivorship and frequency of development to the juvenile stage.

\section{Bioassay of extracts from larvae and adults}

To determine if rejected larvae were chemically defended against fish, crude lipophilic and water-soluble extracts from larvae were mixed together into a palatable squid-based food and offered to Thalassoma (for extracts of tropical invertebrates) or Lagodon (for extracts of temperate invertebrates). The palatable control food, which was readily consumed by fishes, was made by pureeing together squid mantle flesh, an equal volume of distilled water, and sodium alginate at $2 \%$ of the total wet mass. This liquid mixture ("squid paste") was spread into a thin film on a glass plate. A 0.25 $\mathrm{mol} / \mathrm{L}$ solution of calcium chloride $\left(\mathrm{CaCl}_{2}\right)$ poured over the squid paste caused it to solidify and harden somewhat. After $2 \mathrm{~min}$, the calcium chloride solution was rinsed off with distilled water. During this time, the squid paste had become gelatinous with a consistency 
much like that of cooked pasta. We cut this sheet of food into pieces approximately the size of the larvae being assayed.

We compared feeding on solidified squid paste containing invertebrate extracts with feeding on the same squid-based food lacking extracts. These assays were limited to species from which we obtained sufficient biomass of larvae (Callyspongia vaginalis, Calyx podatypa, Bugula neritina, and Eudendrium carneum) or larvae-laden gelatinous mass (Ectyoplasia ferox) for extraction. Before extracting the larvae (or jelly and the larvae it contained for Ectyoplasia), we measured their packed volume, which we call larval volume, in a 1-mL volumetric syringe so that extracts could be added to an appropriate volume of assay food. The fresh larvae were then macerated with a spatula and extracted 3 times with 1:1 dichloromethane/methanol using 3 times the larval volume for each extraction. These extracts were combined in a $20-\mathrm{mL}$ scintillation vial. The solvents were then removed by blowing a stream of nitrogen gas $\left(\mathrm{N}_{2}\right)$ into the vial. This extract was stored under $\mathrm{N}_{2}$ at $-20^{\circ} \mathrm{C}$. After extraction with organic solvents, the larval residue was extracted twice with distilled water, again using 3 times the larval volume for each extraction. This aqueous extract was also reduced to a residue with $\mathrm{N}_{2}$.

To incorporate the crude extract into the squid paste at natural volumetric concentration, we added a volume of squid paste equal to the larval volume to the watersoluble extract. These materials readily mixed together when stirred with a spatula. The organic-soluble portion of the extract was transferred to a small plastic dish using ethanol as the solvent. A steam of $\mathrm{N}_{2}$ evaporated the ethanol. To help disperse the lipophilic extract into the squid paste, ethanol was added back to the lipophilic extract at $1 \%$ of the food volume before adding the squid paste/water soluble compound mixture. The appropriate amount of ethanol also was added to the control food. Pellets of the food containing the larval crude extract and the squid-based control food lacking the extract were offered to fish as previously described. Developing means of retaining water-soluble compounds in assay foods has been problematic; however, because fish rapidly attacked squid pellets, leaching of water-soluble compounds from food pellets prior to a fish attack should have been minimal. Fates of control and treatment pellets were recorded as eaten or rejected. The results were analyzed using Fisher's exact test.

Because adult stages of many benthic invertebrates may be structurally defended against predators (Gerhart et al. 1988, Harvell et al. 1988, Van Alstyne and Paul 1992, Van Alstyne et al. 1992, 1994), thus possibly diminishing the need for a chemically based defense, we also examined the feeding deterrent properties of adult extracts from four of the five species for which data on larval extracts were obtained. Ectyoplasia was excluded because a test of the chemical extracts from adult Ectyoplasia colonies had already been conducted by Pawlik and co-workers (1995) using the same experimental methodology, fish predator, and squid-based assay food. This permitted us to compare larval with adult chemical defenses against fishes for all five species. To conduct these assays, small pieces from several adults were combined and extracted using the methodology described above. Fish feeding assays and data analyses were conducted as described for the larval extracts. Whether our assay fish could consume adults of the species tested is not known, although Thalassoma are reported to forage on gorgonians (Feddern 1965), and siliceous sponge spicules do not diminish Thalassoma feeding when incorporated into palatable foods (Chanas and Pawlik 1995).

\section{Reproductive and larval characteristics vs. larval palatability}

To test the hypothesis that distasteful larvae might commonly advertise this trait by being brightly colored (i.e., aposematic) but that palatable larvae might have less obvious coloration, we classified our larväe as palatable or unpalatable to Thalassoma or Lagodon (Figs. 1, 3, 5, and 6), and as brightly colored (bright red, orange, or yellow) or not brightly colored (see Appendix C). We used Thalassoma and Lagodon to classify larval palatability because we used them most frequently as larval predators for tropical and temperate species, respectively. We also compared the frequency of daytime and nighttime spawning for palatable and distasteful larvae. With daytime spawners, we also included invertebrates that brood larvae externally (i.e., Briareum-E and-U) and invertebrates that place developing larvae in external gelatinous masses (i.e., Ectyoplasia and Xestospongia) because all such larvae are continuously exposed to benthic fishes for several days.

All of the invertebrates that we investigated have lecithotrophic larvae that are brooded or gametes that are shed into the surrounding seawater and fertilized externally (i.e., broadcast spawners). Using Fisher's exact test, we examined whether the proportion of species with distasteful larvae differed significantly between brooders and broadcasters. Because all larvae we investigated lack morphological defenses, we reasoned that distasteful larvae were probably defended chemically. Based on this assumption, we limited this analysis to taxa known to be chemically rich and thus potentially capable of chemically defending their larvae. Thus, we excluded data on the three hard coral species we studied because hard corals are rarely reported to produce secondary metabolites (Faulkner 1993 and reviews cited therein), and no hard coral metabolite is known to deter consumers. Because all broadcast spawners we studied were gorgonians (Appendix C), there could be a taxonomic bias in this comparison. To reduce this potential bias, we expanded this analysis to include results from previous studies reporting the 


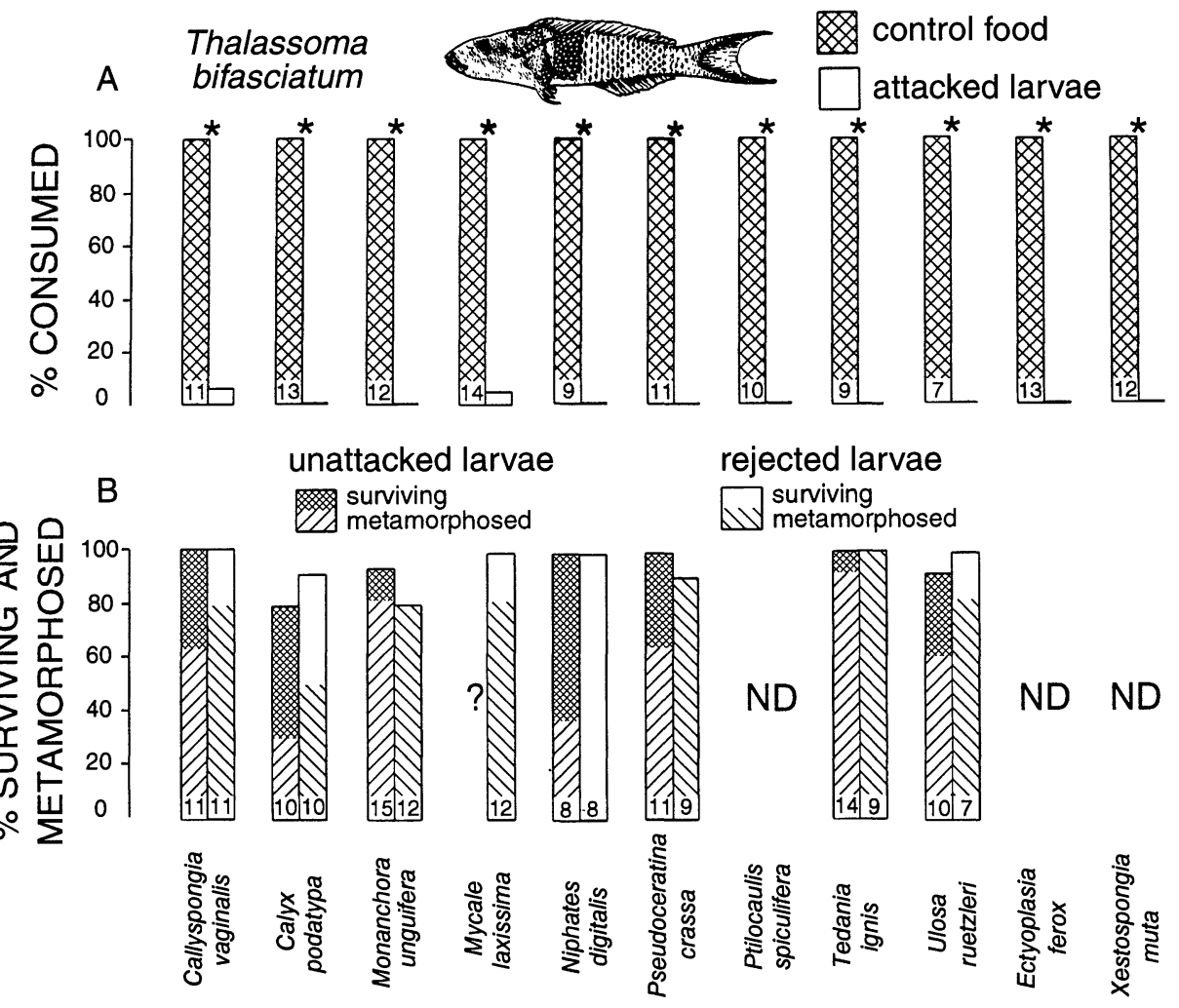

FIG. 1. (A) The percentage of sponge larvae consumed after being mouthed by the Caribbean wrasse Thalassoma bifasciatum. (B) The percentage of larvae remaining alive and the percentage metamorphosed 1-6 d after being mouthed and rejected by Thalassoma. A brine shrimp was the palatable control food. For the survivorship assay, the control consisted of larvae that were not offered to Thalassoma. The number of replicates for each assay is shown at the base of each bar on the histogram. An asterisk indicates a significant $(P \leq 0.05$, Fisher's exact test) difference between treatment and control. In panel B, a question mark (?) indicates that no control group was established for that assay, and ND indicates that larval survivorship was not determined for rejected larvae of that species.

palatability of eggs and larvae from ascidians (reviewed in Lindquist et al. 1992) and sea stars (Lucas et al. 1979, McClintock and Vernon 1990).

\section{RESULTS}

Information on the reproductive mode, timing of larval or gamete release, and larval color and size for all species appear in Appendix C. This information was recorded to facilitate examination of how reproductive mode and larval characteristics may relate to the palatability of marine invertebrate larvae. Except for two pairs of congeners, all species in this study were from separate genera (see Appendix A). Accordingly, except for the two pairs of congeners, we will henceforth use generic names only.

\section{Palatability of sponge larvae}

For all 11 species of Caribbean sponges, larvae or gelatinous larval masses were unpalatable to fishes $(P$ $<0.001$, Figs. $1 \mathrm{~A}$ and $2 \mathrm{~A}$ ). Being mouthed and rejected by fishes had no negative effects on larval survivorship or metamorphic competence (Figs. 1B and 2B). Among all assays with wrasses (Fig. 1A) and damselfish (Fig. $2 \mathrm{~A}$ ), no more than $9 \%$ of the larvae from any sponge species were consumed. In the combined data for both fish species, only 4 of 195 larvae or bite-sized portions of gelatinous larval mass (Ectyoplasia and Xestospongia) were consumed. The palatability of larvae hatched from gelatinous masses was not tested because Thalassoma presented with these small larvae (100-200 $\mu \mathrm{m}$, Appendix C) appeared not to see them.

The survivorship (83-100\%) of sponge larvae attacked and rejected by Thalassoma never differed significantly from that of larvae not attacked by fish (80100\%; Fig. 1B). Metamorphic success among larvae (both attacked and unattacked treatments) was high (64-100\%) for Callyspongia, Monanchora, Mycale, Pseudoceratina, Tedania, and Ulosa, but low (0-50\%) for Calyx and Niphates. Frequency of metamorphosis of attacked larvae was never significantly less than that of unattacked control larvae (Fig. 2B). Among all of these assays, only distasteful larvae of Mycale were damaged (torn into several pieces) when attacked by wrasses. Despite this damage, recovered larval fragments nearly always survived and metamorphosed.

Similarly, the survivorship (78-100\%) of sponge larvae attacked but not consumed by Stegastes never differed significantly from that of unattacked control lar- 
FIG. 2. (A) The percentage of sponge larvae consumed after being mouthed by the Caribbean damselfish Stegastes partitus. (B) The percentage of larvae surviving and metamorphosing 1$4 \mathrm{~d}$ after being mouthed and rejected by Stegastes. Methods and symbols are as in Fig. 1.

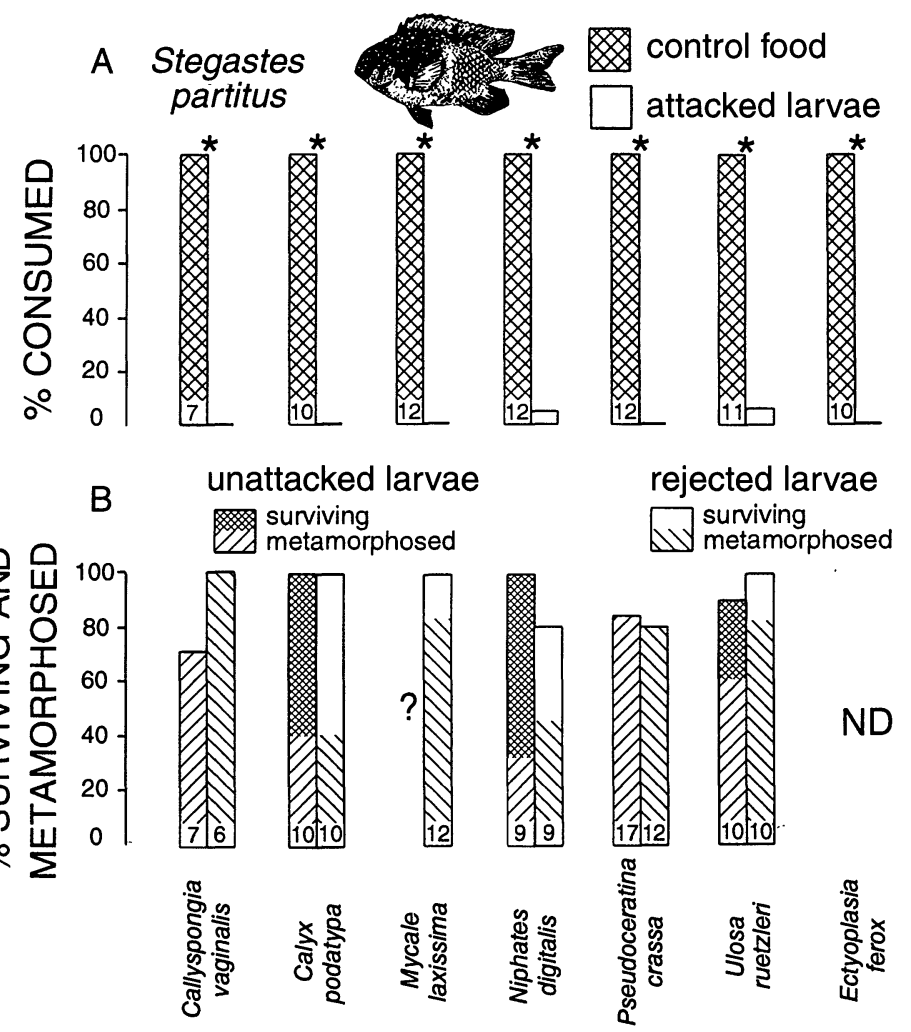

vae (71-100\%, Fig. 2B). Metamorphosis among rejected larvae also was high (75-100\%) for Callyspongia, Mycale, Pseudoceratina, and Ulosa and never differed significantly from unattacked control larvae. Among attacked and unattacked Calyx and Niphates larvae, $33-57 \%$ of surviving larvae in each treatment metamorphosed. Metamorphosis of attacked larvae was not reduced relative to control larvae.

\section{Palatability of gorgonian and hard coral larvae}

In contrast to their uniform rejection of sponge larvae, Thalassoma readily consumed larvae of some gorgonian species but completely rejected others (Fig. 3A). Thalassoma significantly $(P<0.0054)$ rejected larvae of the surface-brooding gorgonians Briareum-E and Briareum-U, the brooding species Eunicea mammosa, and the synchronous broadcast-spawning species Erythropodium and Pseudoplexaura-A. Consumption of the four other species of larvae, Eunicea tourneforti, Plexaura, Plexaurella, and Pseudoplexaura-B (all synchronous broadcast spawners), did not differ significantly from consumption of the control food. These results show that closely related species can differ dramatically in their palatability to Thalassoma, as seen in the contrasts of the two Eunicea spp. and the two types of Pseudoplexaura cf. porosa.

Following attack by Thalassoma, the survivorship of rejected gorgonian larvae was high $(92,100$, and $78 \%$, respectively, for Briareum-E, Briareum-U, and
Pseudoplexaura-A) and indistinguishable from that of controls (Fig. 3B). No settlement or metamorphosis occurred among attacked or unattacked larvae within the 3-5 d observation period. Although we had no unattacked control larvae for Eunicea mammosa, six of six rejected larvae survived.

Among gorgonian larvae offered to Stegastes, larvae of two species (Briareum-E and Eunicea mammosa) that were distasteful to Thalassoma were eaten by Stegastes (Fig. 4). Because our assay methodology minimized among-assay differences in fish hunger by feeding all fishes shortly before the assays, differences between Thalassoma and Stegastes in their willingness to eat the larvae of specific species should reflect consumer-specific differences in resistance to larval defenses rather than between-consumer differences in hunger levels. Stegastes also readily ate all Eunicea tourneforti larvae offered. Only the larvae of Briareum-U were significantly rejected by Stegastes $(P$ $=0.004$, Fig. 4). Survivorship of Briareum-U larvae after attack and rejection by Stegastes was not determined.

In contrast to the general distastefulness of all sponge larvae and several gorgonian larvae, fishes readily consumed larvae of the three hard coral species we tested. Thalassoma consumed 100\% of Agaricia and Porites and $92 \%$ of Siderastrea larvae (Fig. 5). Only larvae of Agaricia were offered to Stegastes, but all were eaten (Fig. 5). 


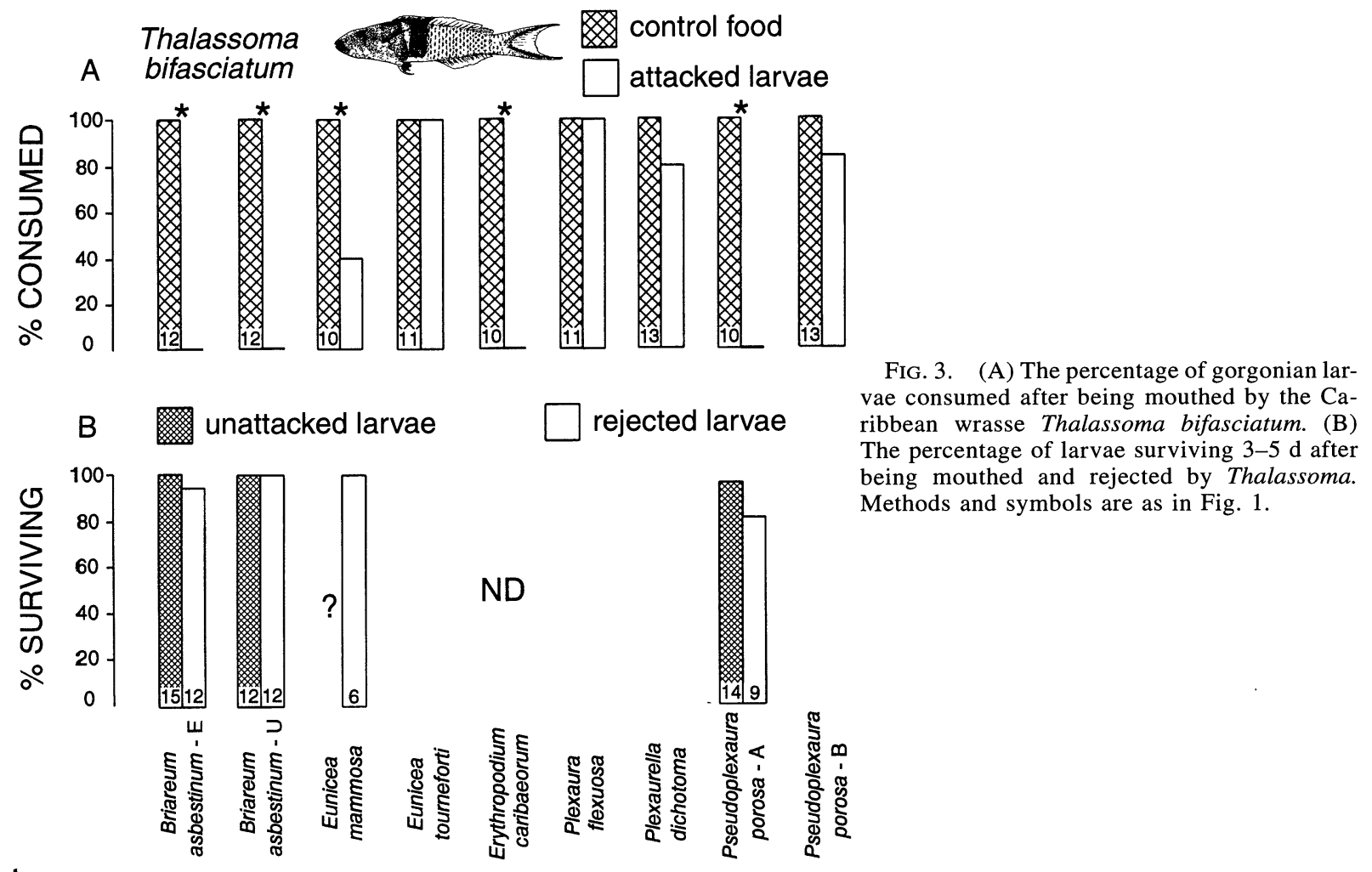

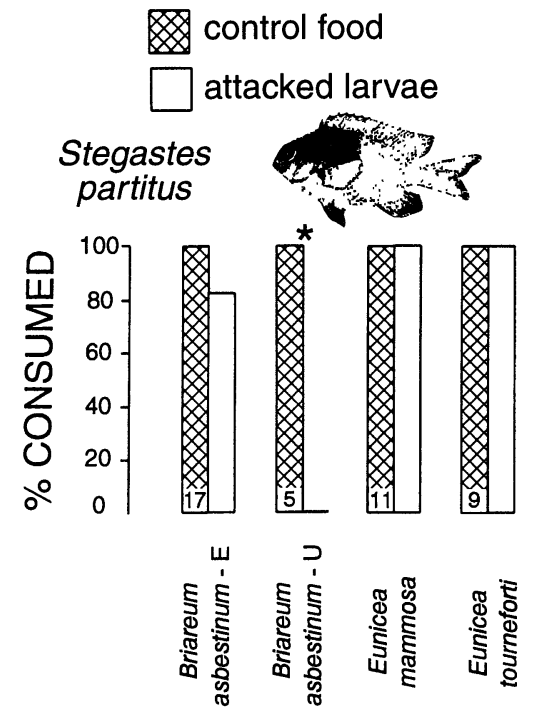

FIG. 4. The percentage of gorgonian larvae consumed after being mouthed by the Caribbean damselfish Stegastes partitus. Methods and symbols are as in Fig. 1.

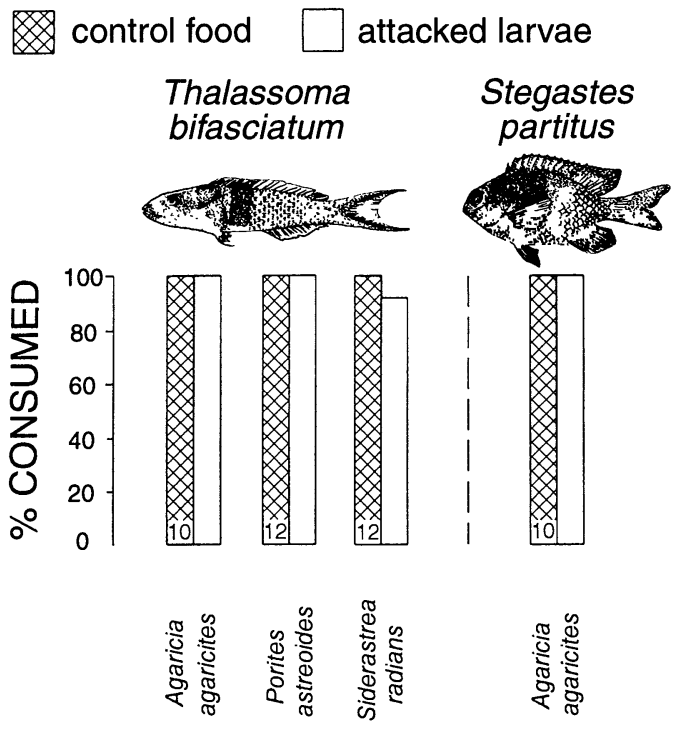

FIG. 5. The percentage of hard coral larvae consumed after attack by the Caribbean wrasse Thalassoma bifasciatum or the damselfish Stegastes partitus. Dashed vertical lines separate assays for the predators shown above the histograms. Methods and symbols are as in Fig. 1. 


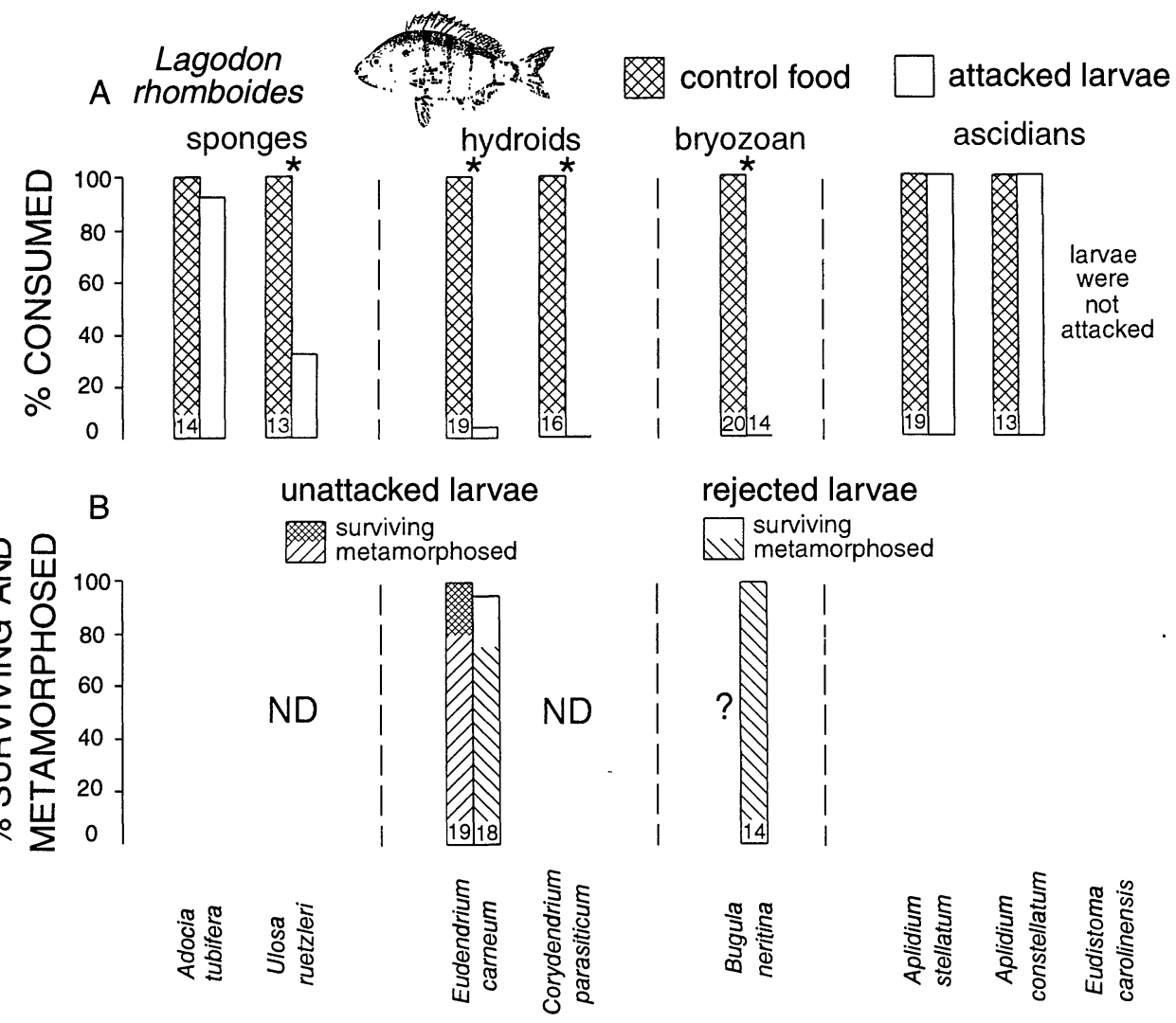

FIG. 6. (A) The percentage of sponge, hydroid, bryozoan, and ascidian larvae consumed after attack by the pinfish Lagodon rhomboides. (B) The percentage of larvae surviving and metamorphosing 1-3 d after being mouthed and rejected by Lagodon. Methods and symbols are as in Fig. 1.

\section{Palatability of temperate invertebrate larvae}

Larvae of the temperate sponge Adocia were readily consumed by Lagodon, while larvae from a temperate population of Ulosa were significantly less palatable ( $P<0.001,33 \%$ consumed) than brine shrimp (Fig. 6A). Larvae of the hydroids Eudendrium and Corydendrium and of the bryozoan Bugula were extremely unpalatable to Lagodon $(P<0.001)$, while larvae of the colonial ascidians Aplidium constellatum and Aplidium stellatum were always eaten (Fig. 6A). The palatability of larvae from the ascidian Eudistoma carolinensis was not determined because Lagodon apparently did not see, and thus did not attack, these nearly transparent larvae.

After $72 \mathrm{~h}$, the survivorship (94\%) and metamorphosis $(72 \%)$ of rejected Eudendrium larvae did not differ significantly from that of unattacked control larvae (100 and 79\%, respectively; Fig. 6B). All Bugula larvae rejected by Lagodon survived and metamorphosed within $24 \mathrm{~h}$ (Fig. 6B).

The file fish Monocanthus consumed significantly fewer Eudendrium larvae (59\%) than brine shrimp and rejected all Bugula larvae sampled (Fig. 7A). Of the 19 Monocanthus offered a Bugula larva, only 6 of these fish attacked larvae. The other fish visually inspected the larvae and then swam away. A brine shrimp was eaten by all 19 fish. Larvae of the ascidian Aplidium stellatum were always consumed by Monocanthus (Fig. 7A). All Bugula larvae attacked and rejected by Monocanthus survived and metamorphosed (Fig. 7B). All attacked and unattacked Eudendrium larvae survived (Fig. 7B), and 79 and $80 \%$, respectively, settled and metamorphosed within $72 \mathrm{~h}$.

\section{Palatability of larval and adult extracts}

Extracts from larvae strongly deterred fish feeding in all five of our assays, whereas adult extracts deterred feeding for only three of the five species (Fig. 8). Crude larval extracts from the Caribbean sponge Callyspongia diminished Thalassoma feeding by $67 \%(P=$ $0.0095)$, while extracts of Bugula larvae reduced $L a$ godon feeding by $60 \%(P<0.001)$. For both species, extracts from adults had no effect on feeding. This dichotomy between the palatability of larval and adult extracts was not apparent for the hydroid Eudendrium or the sponges Calyx or Ectyoplasia, for which extracts from both adults and larvae strongly deterred feeding $(P<0.001)$. 

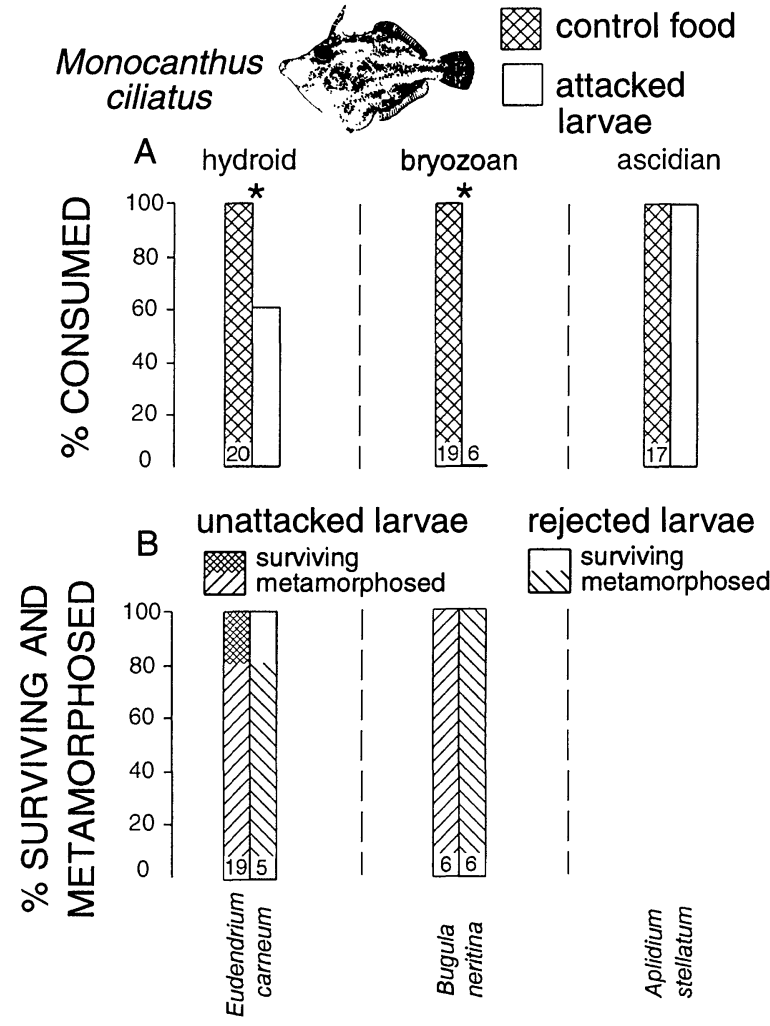

FIG. 7. (A) The percentage of hydroid, bryozoan, and ascidian larvae consumed after attack by the filefish Monocanthus ciliatus. (B) The percentage of larvae surviving and the percentage metamorphosed 1-3 d after being mouthed and rejected by Monocanthus. Methods and symbols are as in Fig. 1.

\section{Color and spawning times of palatable vs. distasteful larvae}

Distasteful larvae were commonly brightly colored and spawned during daylight hours. Twelve of 20 species $(60 \%)$ of distasteful larvae were brightly colored, while none of the 10 palatable species $(0 \%)$ were brightly colored $(P=0.0015$, Fisher's exact test). Twelve of 14 species $(89 \%)$ with distasteful larvae spawned during daylight hours or placed their developing larvae in external, gelatinous masses. In contrast, only two of nine species $(23 \%)$ with palatable larvae spawned during the day ( $P=0.007$, Fisher's exact test).

\section{Palatability of brooded vs. broadcast- spawned larvae}

Among the 27 qualifying species in this study, 2 of 6 broadcasters (33\%, all gorgonians) and 18 of 21 brooders $(86 \%)$ had distasteful larvae. Thus, distasteful larvae were significantly more common among brooding than among broadcast-spawning species $(P=$ 0.024 , Fisher's exact test). In the expanded comparison including data for ascidians and sea stars, 4 of 15 broadcast spawners $(27 \%$, both lecithotrophs and planktotrophs) and 27 of 32 brooders (84\%, all lecithotrophs) had distasteful eggs or larvae. These results support the hypothesis that, among chemically rich taxa, larvae of brooders are more commonly distasteful than eggs or larvae of broadcasters $(P=0.0008$, Fisher's exact test).

\section{DISCUSSION}

It is much more difficult to obtain ecologically meaningful data on larval than on adult stages of marine invertebrates. Therefore, numerous marine investigations of complex life cycles have been forced to rely on fragmentary information regarding processes affecting: (1) larval ecology, (2) the importance of larval limitation in population regulation, and (3) the relative importance of dispersal vs. susceptibility to predation in selecting for patterns of larval development (Thorson 1946, 1950, Vance 1973, Pechenik 1979, Strathmann 1980, 1985, 1986, 1993, Palmer and Strathmann 1981, Grant 1983, Jablonski and Lutz 1983, Babcock et al. 1986, Hines 1986, Jablonski 1986, Jackson 1986, Gaines and Roughgarden 1987, Olson and McPherson 1987, Davis and Butler 1989, Mitton et al. 1989, Stoner $1990)$. With the exception of studies on ascidian larvae (e.g., van Duyl et al. 1981, Olson 1983, Grosberg and Quinn 1986, Young 1986, Olson and McPherson 1987, Young and Bingham 1987, Davis and Butler 1989, Stoner 1990, Bingham and Young 1991), most previous investigations of larval ecology have focused on invertebrate groups in which chemical defenses are rare and in which larvae are usually planktotrophic rather than lecithotrophic (Young and Chia 1987). Thus, because marine larvae from diverse taxa were commonly identified as prey of both benthic and pelagic planktivores (Young and Chia 1987), and because some studies demonstrated that predation on larvae could be intense and have dramatic effects on the distribution and abundance of adults (Gaines and Roughgarden 1987, Olson and McPherson 1987), many investigators have assumed that virtually all larvae are suitable prey for most generalist planktivores. This reasonable, but relatively untested, assumption played a critical role in the formulation of hypotheses and theoretical models focused on factors affecting the evolution of life history patterns among marine invertebrates (see Vance 1973, Strathmann 1980, 1985, 1986, 1993, Rumrill 1990).

In conflict with the assumption of universal larval palatability, our feeding assays demonstrate that larvae from some groups of marine invertebrates are broadly distasteful to fishes (e.g., Caribbean sponges, Figs. 1A and $2 \mathrm{~A}$ ), while larvae from other groups generally appear palatable (e.g., hard corals, Fig. 5). Larval palatability can, however, vary considerably between species within a group, or possibly even between individuals within a species (e.g., gorgonian larvae, Figs. 3 and 4; however see Knowlton [1993] for examples of how our within-species contrasts may really be generated by unrecognized sibling species). The great disparity in larval palatabilities identified in this study, 
control food pellets

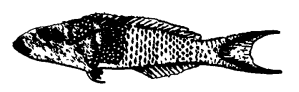

Thalassoma bifasciatum
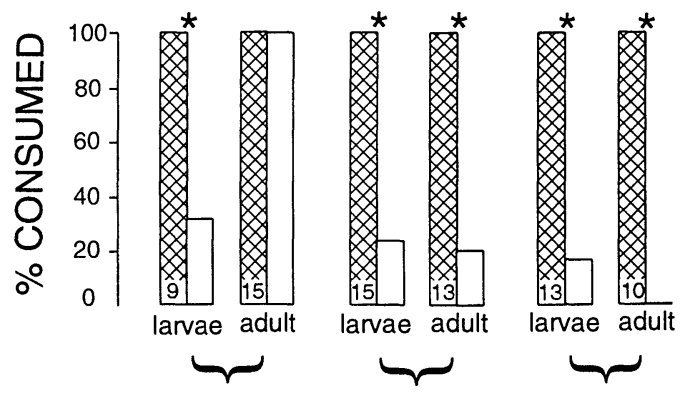

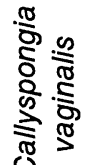
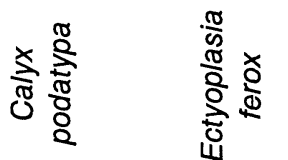

treatment food pellets

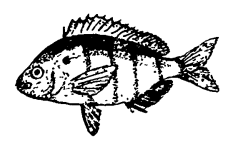

Lagodon rhomboides
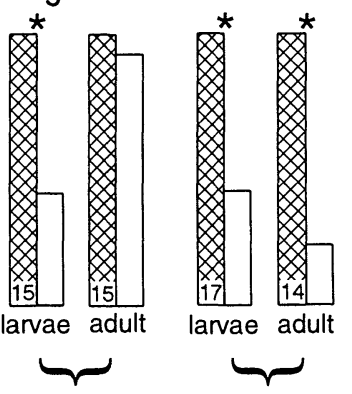

ฺุ

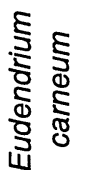

FIG. 8. Consumption by the Caribbean wrasse Thalassoma bifasciatum and the temperate pinfish Lagodon rhomboides of control food pellets and treatment food pellets containing larval or adult crude extracts from Caribbean sponges (Callyspongia vaginalis, Calyx podatypa, and Ectyoplasia ferox) and temperate invertebrates (the bryozoan Bugula neritina and the hydroid Eudendrium carneum), respectively. Control food pellets were a squid-based food, and treatment pellets consisted of the squid-based food plus the larval or adult crude extract at its natural volumetric concentration. The number of replicates

- for each assay is shown at the base of each bar on the histogram. Other symbols are as in Fig. 1. Data for Ectyoplasia ferox adults are from Pawlik et al. (1995).

and in results of previous studies on invertebrate egg and larval chemical defenses (Lucas et al. 1979, Young and Bingham 1987, McClintock and Vernon 1990, Lindquist et al. 1992), forcefully argues for a re-evaluation of the general perception that most marine larvae are suitable prey for most planktivores. Our findings that many larvae are unpalatable and remain undamaged following attack and rejection by fishes should allow further refinements in theoretical models exploring the evolution of invertebrate life history patterns. As one example of how such data can affect theoretical efforts, when stage-specific differences in larval susceptibility to predation were demonstrated for planktotrophic invertebrates (Rumrill et al. 1985, Pennington et al. 1986), this realization altered the form of theoretical analyses exploring relationships among adult fecundity, parental investment per embryo, duration of the free-swimming larval stage, and rate of larval mortality (Rumrill 1990).

Because brooded larvae that develop using yolk (lecithotrophs) rather than by feeding in the plankton are typically large, easy to see, and lack morphological characteristics that diminish fish predation on longer lived, planktotrophic larvae (Pennington and Chia 1984, Morgan 1989), their survival in habitats teeming with planktivorous fishes frequently may depend on chemical defenses. Our feeding assays (Figs. 1-4, 6, and 7) demonstrate that lecithotrophic larvae from numerous species of sponges, hydroids, gorgonians, and bryozoans are distasteful to co-occurring fishes and that their distastefulness can be due to chemical defenses (Fig. 8). Additionally, for the taxa we studied, the differing proportion of brooding vs. broadcast-spawning invertebrates with distasteful larvae ( 83 vs. $31 \%$, respectively) strongly suggests that longer lived larvae of broadcast-spawning invertebrates are typically more palatable to fishes than the more rapidly settling larvae of sessile invertebrates that brood. Although Olson and McPherson (1987) found that intense fish predation on large brooded larvae of the ascidian Lissoclinum patella effectively excludes this animal from reef areas to which it is physiologically suited, our study, as well as ones by Young and Bingham (1987) and Lindquist and co-workers (1992), suggests that the large conspicuous larvae of many sessile benthic invertebrates are chemically defended and thus well adapted to consumer-rich habitats.

In addition to distastefulness, other larval characteristics can sometimes provide defense against predation. These include: (1) larval brooding inside the adult or egg placement in tough capsules or gelatinous masses (Thorson 1946, 1950, Mileikovsky 1971, Pechenik 1979), (2) escapes in space and time (Forward 1976a, Forward and Cronin 1978, Robertson and Howard 1978, Babcock et al. 1986, Christy 1986), (3) morphological defenses (Pennington and Chia 1984, Morgan 1989), (4) larval evasion behaviors elicited by predators (Singarajah 1969, 1975, Forward 1976b, 
1977, Rumrill et al. 1985, Pennington et al. 1986), and (5) small body size and transparency (Brooks and Dobson 1965, Zaret and Kerfoot 1975, Hobson and Chess 1976, Lindquist et al. 1992).

\section{Chemical defenses of invertebrate larvae}

Over the past three decades, chemical investigations of adult marine invertebrates showed that relatively soft-bodied sponges, hydroids, gorgonians, soft corals, bryozoans, and ascidians contain an enormous variety of bioactive secondary metabolites (Faulkner 1993). Numerous studies under both laboratory and field conditions have demonstrated that these secondary compounds commonly function as defenses against consumers (Paul 1992, Pawlik 1993, Pawlik et al. 1995). In contrast, there are few reports of secondary metabolites from morphologically defended or highly mobile invertebrates such as shelled gastropods, crustaceans, scleractinian corals, and polychaetes (Faulkner 1993). This observed distribution of secondary metabolites suggests that mobility, hard body parts, and, in some instances, the ability to fight off predators may have reduced selection for chemical defenses among these invertebrates. Slow-moving echinoderms that produce saponins (i.e., asteroids and holothurians), which can defend both larval and adult stages, constitute an exception to this general pattern for mobile invertebrates (Lucas et al. 1979, Bingham and Braithwaite 1986, McClintock and Vernon 1990, Paul 1992).

Early studies suggested that embryos were doomed to be "tasty" (Orians and Janzen 1974) because rapidly developing young tissues and toxic chemicals were biologically incompatible. However, recent marine studies have demonstrated that larvae can be chemically defended by toxic metabolites (Lindquist et al. 1992, Lindquist and Hay 1995), and we commonly found chemically defended larvae among the diverse invertebrates that we assayed. Larval chemical defenses against fishes occurred in each of the three sponges (Callyspongia, Calyx, and Ectyoplasia), one bryozoan (Bugula), and one hydroid (Eudendrium) that we chemically examined (Fig. 8). Because extracts from unpalatable larvae were deterrent in each of the five species we tested and because these tests included three different invertebrate groups, we suspect that other distasteful larvae are defended by similar means.

Chemically unpalatable larvae are common in unrelated, but chemically rich, taxa of sessile invertebrates. This observation suggests that the ability of adults to produce noxious compounds is coupled to a species' ability to defend chemically its larval stages. In some species, however, production of defensive metabolites in larval stages may be decoupled from production of adult defenses. Indeed, in the five species for which we examined both larvae and adults, larval extracts deterred fishes in all cases, while adult extracts deterred feeding in only three of five cases (Fig. 8). For adults of some species, physical features such as mineralized skeletons, spicules, or tough structural fibers may provide sufficient protection against predators (Gerhart et al. 1988, Harvell et al. 1988, Van Alstyne and Paul 1992, Van Alstyne et al. 1992, 1994; but see Lindquist et al. 1992, Chanas and Pawlik 1995) and thus diminish the need for chemically based defenses in adults. Alternatively, structural and chemical defenses could act synergistically in adults and lessen the need for high levels of chemical defenses alone (Hay et al. 1994).

The sponges Ectyoplasia and Xestospongia densely pack developing embryos and larvae into gelatinous masses that are released onto the reef. Many other sponges (Ayling 1980, Fromont 1988, Fromont and Bergquist 1994) and nudibranchs (Pawlik et al. 1988) exhibit similar patterns. Pawlik and co-workers (1988) showed that the bright pink egg masses of the Spanish Dancer nudibranch Hexabranchus sanguineus were chemically defended against fishes, and we found that the bright orange egg masses of Ectyoplasia were also chemically unpalatable (Fig. 8).

\section{Patterns of spawning, larval palatability, and accessibility to predators}

Because larvae of sessile invertebrates that brood are generally large enough to be easily detected by dayactive fishes and typically may remain near the bottom where predation by fishes can be intense, they likely experience strong selection to deter or avoid fishes. In contrast, eggs, embryos, and early stage larvae of external fertilizers are commonly smaller than brooded larvae, are frequently buoyant, and often float away from the bottom. Consequently, broadcast-spawned egg and larval stages may experience less intense selection to deter feeding by benthic fishes. This hypothesis was supported by our findings that distasteful larvae were significantly more common among brooding than broadcast-spawning species.

Marine invertebrates that brood may do so on their external surfaces or, more commonly, within adult tissues. Invertebrates that brood larvae on their external surfaces, such as some gorgonians (Brazeau and Lasker 1990) and soft corals (Benayahu and Loya 1983, Alino and Coll 1989), produce larvae that are easily accessible to fishes. In these species, developing larvae are often present in large numbers and commonly adhere to adult surfaces for 3-5 d. Because these larvae would be easy for consumers to find and harvest (they were for us), larval defenses may be especially important for species that surface brood. Our findings are consistent with this hypothesis. When fed to fish, surfacebrooded gorgonian larvae from the two species of Briareum were generally unpalatable, although Stegastes differed from Thalassoma in consuming larvae of the encrusting form of Briareum (Figs. 3A and 4). In contrast to the general distastefulness of these surfacebrooded gorgonian larvae and of internally brooded larvae from Eunicea mammosa, larvae from four of the 
six gorgonian species that are synchronous broadcast spawners were readily eaten (Fig. 3). These broadcastspawning gorgonians all spawn at night when visually acute fishes are inactive. Thus, nocturnal spawning provides an escape from day-active fishes and therefore likely diminishes selection for larval chemical defenses, even though adult stages of broadcast-spawning gorgonians can be chemically defended (Pawlik et al. 1987). Most hard corals also spawn at night and have relatively large eggs and larvae that are palatable to fishes (Fig. 5, Westneat and Resing 1988). Unlike Caribbean gorgonians, Caribbean hard corals rarely contain unusual secondary metabolites (Faulkner 1986, 1992), and may, therefore, be unable to defend chemically their gametes or larvae. Additionally, mass synchronous spawning among many benthic invertebrates, including gorgonians and hard corals, could further diminish losses to predators by satiating local planktivores that feed at night (Harrison et al. 1984, Bowden et al. 1985, Babcock et al. 1986, Benayahu and Loya 1986, Westneat and Resign 1988).

In contrast, brooding sponges, hydroids, ascidians, and bryozoans that produce distasteful larvae (Figs. 17, Young and Bingham 1987, Lindquist et al. 1992) often release their larvae during daylight hours (Appendix C, Svane and Young 1989; N. Lindquist, un- published data) when larvae would be most apparent to fishes. Existence of this pattern suggests that there may be some advantage to daytime release once predation has been diminished by larval chemical defenses (see Discussion: Larval palatability and timing of settlement below).

Prey pigmentation also affects susceptibility to fish predation by making prey more visually obvious (Zaret and Kerfoot 1975, Hobson and Chess 1976). However, Young and Bingham (1987) showed that bright pigmentation of chemically distasteful larvae could function as warning coloration to fishes. They suggested that aposematic coloration might be common among chemically defended larvae. Results of our investigation support their hypothesis in that $60 \%$ of the species with unpalatable larvae (12 of 20 species) were brightly colored (bright red, orange, or yellow), while none of the species with palatable larvae ( 0 of 10 species) were brightly colored (Appendix C, $P=0.0015$, Fisher's exact test), although some were faint shades of pink, brown, lavender, orange, or yellow.

\section{Larval palatability and timing of settlement}

Despite the predation risks associated with day-active larvae, daytime settlement might be advantageous for sessile invertebrates because it would allow their larvae to use strong photic cues in selecting appropriate habitats for their benthic stages. As an example, Olson (1983) demonstrated that newly settled ascidians on shallow patch reefs died within days when exposed to full or UV-filtered sunlight, while shaded juveniles at the same depth $(\approx 2 \mathrm{~m})$ survived. Based on these ob- servations, he proposed that midday larval release, rapid settlement, and photonegative behavior at settlement allowed larvae of tropical ascidians to choose photically appropriate settlement sites during times when light stress would be most intense. Selecting settlement sites based on photic cues should be difficult, if not impossible, at night. Among colonial ascidians, virtually all larvae are released and likely settle during daylight hours (Hurlbut 1988, Svane and Young 1989, Bingham and Young 1991). Distastefulness is also typical of conspicuous ascidian larvae in tropical habitats (Young and Bingham 1987, Lindquist et al. 1992).

Because juvenile sponges (Callyspongia, Mycale, Niphates, Pseudoceratina, and Tedania) settling on exposed substrates in shallow water (down to at least 3 m) are quickly killed by natural levels of UV radiation (N. Lindquist, unpublished data), daytime larval release and settlement also should be advantageous for many tropical sponges. The general distastefulness of sponge larvae (Figs. 1 and 2) would allow them to evaluate settlement sites during daylight hours without undue risk of fish predation. At least 5 of the 11 sponge species we studied (Callyspongia, Mycale, Niphates, Pseudoceratina, and Tedania) release larvae during daylight hours (Appendix C). No data are available on timing of larval release for the other six sponge species used in our study, but daytime spawning has been observed for other sponges (Ayling 1980, Hoppe and Reichert 1987, Fromont 1988, Fromont and Bergquist 1994). We do not know how long sponge larvae swim before settling under field conditions, but in clean plastic dishes in the laboratory, these larvae typically settled and metamorphosed within $24 \mathrm{~h}$ of spawning ( $\mathrm{N}$. Lindquist, personal observation). Laboratory studies have tended to overestimate the length of the freeswimming period for ascidian larvae (van Duyl et al. 1981, Olson 1983); this could also be true for sponges.

\section{Larval survivorship after attack and rejection by predators}

Because of their modular body plans, colonial invertebrates can tolerate some tissue loss to predators without a large reduction in fitness (Jackson 1977, 1985, Ayling 1981, Davis 1988). Their larvae, however, are functionally solitary individuals and small enough to be entirely consumed in a single bite by planktivorous fishes. An intriguing outcome of our feeding assays was that distasteful larvae rarely appeared damaged, even after enduring multiple attacks by fishes. Additionally, sponge, hydroid, and bryozoan larvae attacked and rejected by fish settled and metamorphosed at rates statistically indistinguishable from unattacked controls (Figs. 1B, 2B, 6B, and 7B). Young and Bingham (1987) noted a similar outcome for chemically defended larvae of an ascidian that were attacked and rejected by the pinfish Lagodon rhomboides. If, under natural conditions, the survival of distasteful larvae is high, this has important implications for the de- 
mography of some sessile invertebrates and the evolution of larval chemical defenses. Results of our study and of in situ observations of ascidian larval behavior, survival, and settlement (Davis and Butler 1989, Bingham and Young 1991) suggest that population bottlenecks might occur most frequently at the juvenile rather than the larval stage for many sessile benthic invertebrates with unpalatable larvae that settle soon after spawning. In contrast, several studies of benthic invertebrates with palatable larvae (Bernstein and Jung 1979, Gaines and Roughgarden 1987, Olson and McPherson 1987, Young and Chia 1987) indicate that intense predation can reduce the number of larvae enough to affect the distribution and abundance of adults.

Because the survival of larvae attacked and rejected by fishes was uniformly high, selection for characteristics that decrease larval palatability to predators could occur at the level of an individual larva. Thus, it is not necessary to evoke group-selection or kin-selection arguments to explain the evolution of larval chemical defenses. However, because philopatry (i.e., settling near one's parents) appears common among colonial benthic invertebrates (Jackson 1986) and can result in dense, genetically closed populations (Grosberg and Quinn 1986, Davis and Butler 1989, Brazeau and Harvell 1994), kin selection could facilitate the evolution - of chemical defenses in both larval and adult stages.

\section{Conclusions}

Among benthic invertebrates, postsettlement survivorship has been proposed to be enhanced by both increasing larval size and decreasing the distance of larval dispersal (Jackson 1985, 1986). These characteristics would, however, potentially increase larval apparency to benthic fishes. Because of their large size, lack of morphological defenses, inability to elude predators, and frequent daytime presence on the reef, quickly settling larvae of many brooding sessile invertebrates could profit from being distasteful to fishes and other planktivores. Results of our feeding assays with sponge, gorgonian, hydroid, and bryozoan larvae (Figs. $1-4,6-7$ ), and separate studies of ascidian (Young and Bingham 1987, Davis and Butler 1989, Lindquist et al. 1992) and asteroid (Yamaguchi 1973, 1974, Lucas et al. 1979, McClintock and Vernon 1990) larvae all demonstrate that larvae of many taxonomically diverse invertebrates are commonly distasteful to benthic fishes. Their unpalatability can often be attributed to chemical defenses (Lucas et al. 1979, Young and Bingham 1987, McClintock and Vernon 1990, Lindquist et al. 1992; Fig. 8), which also are common in adult stages of these invertebrates (Pawlik et al. 1987, Paul 1992, Pawlik 1993, Pawlik et al. 1995).

When large conspicuous larvae are distasteful, they can stay near the bottom, co-occur with fishes, and yet not be consumed. Having chemically defended larvae should allow species to exhibit reproductive and larval characteristics selected more by the fitness-related con- sequences of larval development mode and dispersal distance than by the necessity of avoiding benthic fishes by producing larvae that are night active or that move away from benthic habitats and develop in the plankton. Our findings that unpalatable larvae are most common among invertebrates that brood rather than broadcast spawn and whose larvae appear to settle locally near adults rather than to disperse over long distances are supportive of hypotheses advanced by Jackson (1986) and Strathmann (1980, 1985, 1993). Jackson argued that retention of larvae near parental habitats would often enhance fitness more than having larvae broadly dispersed in the plankton, and Strathmann argued that the evolution of broadly dispersing planktotrophic larvae may have arisen more from the need to escape predator-rich benthic habitats than from advantages of long-distance dispersal. Additional studies on the palatability of larvae from taxonomically diverse benthic invertebrates should provide a more thorough understanding of (1) factors affecting the survival of invertebrate larvae, (2) larval characteristics purported to deter predators, and (3) factors promoting the diversity of life history strategies among marine invertebrates.

\section{ACKNOWLEDGMENTS}

Support was provided by the National Undersea Research Center (NURC) at the University of North Carolina-Wilmington to NL under NOAA grant numbers NA88AA-DUR004 and NA36RU0060. Additional funding was provided by NSF grants OCE 89-15304 (NL), OCE 89-11872 (MH), OCE 92-02847 (MH), CHE 90-08621 (W. Fenical). Comments by James Estes, Joe Pawlik, Jay Stachowicz, Richard Vance, Richard Zimmer-Faust, and two anonymous reviewers improved the manuscript. The NURC staff in Florida (Steven Miller, Catherine Liipfert, Tom Potts, and Dave Ward) were exceptionally helpful in expediting our investigations. Gerry Wellington and Howard Lasker provided information on spawning times for corals and gorgonians, respectively. Mike Deal, Jay Stachowicz, and Walton Cephas provided assistance in the field and with feeding assays. Assistance with invertebrate identifications was provided by Joe Pawlik (sponges), Howard Lasker (gorgonians), Gerry Wellington (hard corals), Dave Calder (hydroids), and William Kirby-Smith (ascidians).

\section{Literature Cited}

Alino, P. M., and J. C. Coll. 1989. Observations of the synchronized mass spawning and postsettlement activity of octocorals on the Great Barrier Reef, Australia: biological aspects. Bulletin of Marine Science 45:697-707.

Ayling, A. L. 1980. Patterns of sexuality, asexual reproduction and recruitment in some subtidal marine demospongiae. Biological Bulletin 158:271-282.

Ayling, A. M. 1981. The role of biological disturbance in temperate subtidal encrusting communities. Ecology 62: 830-847.

Babcock, R. C., G. D. Bull, P. L. Harrison, A. J. Heyward, J. K. Oliver, C. C. Wallace, and B. L. Willis. 1986. Synchronous spawning of 105 scleractinian coral species on the Great Barrier Reef. Marine Biology 90:379-394.

Barnes, R. D. 1985. Invertebrate zoology. Fifth edition. Saunders College Publishing, New York, New York, USA. Bayer, F. M. 1961. The shallow water octocorallia of the 
West Indian Region. Niojhoff, The Hague, The Netherlands.

Benayahu, Y., and Y. Loya. 1983. Surface brooding in the red sea soft coral Parerythropodium fulvum (Forskal, 1775). Biological Bulletin 165:353-369.

Benayahu, Y., and Y. Loya. 1986. Sexual reproduction of a soft coral: synchronous and brief annual spawning of Sarcophyton glaucum (Quoy \& Gaimard, 1833). Biological Bulletin 170:32-42.

Bernstein, B. B., and N. Jung. 1979. Selective pressures and coevolution in a kelp canopy community in Southern California. Ecological Monographs 49:335-355.

Bingham, B. L., and L. F. Braithwaite. 1986. Defensive adaptations of the dendrochirote holothurian Psolus chitonoides. Journal of Experimental Marine Biology and Ecology 98:311-322.

Bingham, B. L., and C. M. Young. 1991. Larval behavior of the ascidian Ecteinascidia turbinata Herdman: an in situ experimental study of the effect of swimming on dispersal. Journal of Experimental Marine Biology and Ecology 145: 189-204.

Bowden, B., J. Coll, D. Tapiolas, and R. Willis. 1985. Some chemical aspects of spawning in alcyonacean corals. Proceedings of the Fifth International Coral Reef Congress, Tahiti 4:325-329.

Brazeau, D. A., and C. D. Harvell. 1994. Genetic structure of local populations and divergence between growth forms in a clonal invertebrate, the Caribbean octocoral Briareum asbestinum. Marine Biology 119:53-60.

Brazeau, D. A., and H. R. Lasker. 1990. Sexual reproduction and external brooding by the Caribbean gorgonian Briareum asbestinum. Marine Biology 104:465-474.

Brooks, J. L., and S. I. Dobson. 1965. Predation, body size, and composition of plankton. Science 150:28-35.

Burton, R. S. 1986. Evolutionary consequences of restricted gene flow among natural populations of the copepod, $\mathrm{Ti}$ griopus californicus. Bulletin of Marine Science 39:526535.

Chanas, B., and J. R. Pawlik. 1995. Defenses of Caribbean sponges against predatory reef fish: II. Spicules, tissue toughness, and nutritional quality. Marine Ecology Progress Series 127:195-211.

Christy, J. H. 1986. Timing of larval release by intertidal crabs on an exposed shore. Bulletin of Marine Science 39: 176-191.

Darcy, G. H. 1985. Synopsis of biological data on the pinfish Lagodon rhomboides (Pisces: Sparidae). National Oceanic and Atmospheric Administration Technical Report NMFS 23.

Davis, A. R. 1988. Colony regeneration following damage and size-dependent mortality in the Australian ascidian Podoclavella moluccensis Sluiter. Journal of Experimental Marine Biology and Ecology 123:269-285.

Davis, A. R., and A. L. Butler. 1989. Direct observations of larval dispersal in the colonial ascidian Podoclavella moluccensis Sluiter: evidence for closed populations. Journal of -Experimental Marine Biology and Ecology 127:189203.

Emery, A. R. 1973. Comparative ecology and functional osteology of fourteen species of damselfish (Pisces: Pomacentridae) at Alligator Reef, Florida Keys. Bulletin of Marine Science 23:649-770.

Faulkner, D. J. 1986. Marine natural products. Natural Products Report 3:1-33.

1992. Marine natural products. Natural Products Report 9:323-364.

1993. Marine natural products. Natural Products Report 10:497-539.

Feddern, H. A. 1965. The spawning, growth, and general behavior of the bluehead wrasse, Thalassoma bifasciatum (Pisces: Labridae). Bulletin of Marine Science 15:896-941. Forward, R. R., Jr. 1976a. Light and vertical migration: photobehavior and photophysiology of plankton. Pages 157209 in K. C. Smith, editor. Photochemical and photobiological reviews. Plenum Press, New York, New York, USA. 1976b. A shadow response in a larval crustacean. Biological Bulletin 151:126-140.

1977. Occurrence of a shadow response among brachyuran larvae. Marine Biology 39:331-341.

Forward, R. R., Jr., and T. W. Cronin. 1978. Crustacean larval phototaxis: possible functional significance. Pages 253261 in D. S. McLusky and A. J. Berry, editors. Physiology and behavior of marine organisms. Pergamon, London, England.

Fromont, J. 1988. Aspects of the reproductive biology of Xestospongia testudinaria (Great Barrier Reef). Proceedings of the Sixth International Coral Reef Symposium, Australia 2:685-691.

Fromont, J., and P. R. Bergquist. 1994. Reproductive biology of three species of the genus Xestospongia (Porifera: Demospongiae: Petrosida) from the Great Barrier Reef. Coral Reefs 13:119-126.

Gaines, S. D., and J. Roughgarden. 1987. Fish in offshore kelp forests affect recruitment to intertidal barnacle populations. Science 235:479-481.

Gerhart, D. J., D. Rittschof, and S. W. Mayo. 1988. Chemical ecology and the search for marine antifoulants. Journal of Chemical Ecology 14:1905-1917.

Grahame, J., and G. M. Branch. 1985. Reproductive patterns of marine invertebrates. Oceanography and Marine Biology, an Annual Review 23:373-398.

Grant, A. 1983. On the evolution of brood protection in marine benthic invertebrates. American Naturalist 122: 549-555.

Grosberg, R. K., and J. F. Quinn. 1986. The genetic control and consequences of kin recognition by the larvae of a colonial marine invertebrate. Nature 322:456-459.

Harrison, P. L., R. C. Babcock, G. D. Bull, J. K. Oliver, C. C. Wallace, and B. L. Willis. 1984. Mass spawning in tropical reef corals. Science 223:1186-1188.

Harvell, C. D., W. Fenical, and C. H. Greene. 1988. Chemical and structural defenses of Caribbean gorgonians (Pseudopterogorgia spp). I. Development of an in situ feeding assay. Marine Ecology Progress Series 49:287-294.

Hay, M. E., Q. E. Kappel, and W. Fenical. 1994. Synergisms in plant defenses against herbivores: interactions of chemistry, calcification, and plant quality. Ecology 75:17141726.

Highsmith, R. C. 1985. Floating and algal rafting as potential dispersal mechanisms in brooding invertebrates. Marine Ecology Progress Series 25:169-179.

Hines, A. H. 1986. Larval problems and perspectives in life histories of marine invertebrates. Bulletin of Marine Science 39:506-525.

Hobson, E. S., and J. R. Chess. 1976. Trophic interactions among fishes and zooplankters near shore at Santa Catalina Island, California. U.S. Fish and Wildlife Service Fisheries Bulletin 74:567-598.

Hoppe, W. F., and M. J. M. Reichert. 1987. Predictable annual mass release of gametes by the coral reef sponge $\mathrm{NeO}$ fibularia nolitangere (Porifera: Desmospongiae). Marine Biology 94:277-285.

Humann, P. 1993a. Reef creature identification. New World Publications, Jacksonville, Florida, USA.

- 1993b. Reef coral identification. New World Publications, Jacksonville, Florida, USA.

Hurlbut, C. J. 1988. Diel timing of larval release and settlement of colonial tunicates in Pearl Harbor, Oahu, Hawaii. 
Proceedings of the Sixth International Coral Reef Symposium, Australia 2:733-737.

Jablonski, D. 1986. Larval ecology and macroevolution in marine invertebrates. Bulletin of Marine Science 39:565587.

Jablonski, D., and R. A. Lutz. 1983. Larval ecology of marine benthic invertebrates: paleobiological implications. Biological Reviews 58:21-89.

Jackson, J. B. C. 1977. Competition on marine hard substrata: the adaptive significance of solitary and colonial strategies. American Naturalist 111:743-767.

1985. Distribution and ecology of clonal and aclonal benthic invertebrates. Pages 297-355 in J. B. C. Jackson, L. W. Buss, and R. E. Cook, editors. Population biology and evolution of clonal organisms. Yale University Press, New Haven, Connecticut, USA.

1986. Modes of dispersal of clonal benthic invertebrates: consequences for species' distributions and genetic structure of local populations. Bulletin of Marine Science 39:588-606.

Knowlton, N. 1993. Sibling species in the sea. Annual Review of Ecology and Systematics 24:189-216.

Knowlton, N., and J. B. C. Jackson. 1994. New taxonomy and niche partitioning on coral reefs: jack of all trades or master of some? Trends in Ecology and Evolution 9:7-9.

Lindquist, N. 1996. Larval palatability to corals and sea anemones. Marine Biology, in press.

Lindquist, N., and M. E. Hay. 1995. Can small rare prey be chemically defended? The case for marine larvae. Ecology 76:1347-1358.

Lindquist, N., M. E. Hay, and W. Fenical. 1992. Defense of ascidians and their conspicuous larvae: adult vs. larval chemical defenses. Ecological Monographs 62:547-568.

Lucas, J. S., R. J. Hart, M. E. Howden, and R. Salathe. 1979. Saponins in eggs and larvae of Acanthaster planci (L.) (Asteroidea) as chemical defenses against planktivorous fish. Journal of Experimental Marine Biology and Ecology 40:155-165.

McClintock, J. B., and J. D. Vernon. 1990. Chemical defense in the eggs and embryos of Antarctic sea stars (Echinodermata). Marine Biology 105:491-495.

Mileikovsky, S. A. 1971. Types of larval development in marine bottom invertebrates, their distribution, and ecological significance: a re-evaluation. Marine Biology 10: 193-213.

Mitton, J. B., C. J. Berg, Jr., and K. S. Orr. 1989. Population structure, larval dispersal, and gene flow in the Queen Conch, Strombus gigas, of the Caribbean. Biological Bulletin 177:356-362.

Morgan, S. G. 1989. Adaptive significance of spination in estuarine crab zoeae. Ecology 70:464-482.

Olson, R. R. 1983. Ascidian-prochloron symbiosis: the role of larval photoadaptations in midday larval release and settlement. Biological Bulletin 165:221-240.

Olson, R. R., and R. McPherson. 1987. Potential vs. realized larval dispersal: fish predation on larvae of the ascidian Lissoclinum patella (Gottschaldt). Journal of Experimental Marine Biology and Ecology 110:245-256.

Orians, G. H., and D. H. Janzen. 1974. Why are embryos so tasty? American Naturalist 108:581-592.

Palmer, A. R., and R. R. Strathmann. 1981. Scale of dispersal in varying environments and its implication for life histories of marine invertebrates. Oecologia 48:308-318.

Paul, V. J. 1992. Ecological roles of marine secondary metabolites. Cornell University Press, Ithaca, New York, USA

Pawlik, J. R. 1993. Marine invertebrate chemical defenses. Chemical Reviews 93:1911-1922.

Pawlik, J. R., M. T. Burch, and W. Fenical. 1987. Patterns of chemical defense among Caribbean gorgonian corals: a preliminary survey. Journal of Experimental Marine Biology and Ecology 108:55-56.

Pawlik, J. R., B. Chanas, R. T. Tooten, and W. Fenical. 1995. Defenses of Caribbean sponges against predatory reef fish. I. Chemical deterrency. Marine Ecology Progress Series 127:183-194

Pawlik, J. R., M. R. Kernan, T. F. Molinski, M. K. Harper, and D. J. Faulkner. 1988. Defensive chemicals of the Spanish Dancer nudibranch, Hexabranchus sanguineus, and its egg ribbons: macrolides derived from a sponge diet. Journal of Experimental Marine Biology and Ecology 119:99-109.

Pechenik, J. A. 1979. Role of encapsulation in invertebrate life histories. American Naturalist 114:859-870.

Pennington, J. T., and F.-S. Chia. 1984. Morphological and behavioral defenses of trochophore larvae of Sabellaria cementarium (Polychaeta) against four planktonic predators. Biological Bulletin 167:168-175.

Pennington, J. T., S. S. Rumrill, and F.-S. Chia. 1986. Stagespecific predation upon embryos and larvae of the Pacific sand dollar, Dendraster excentricus, by 11 species of common zooplanktonic predators. Bulletin of Marine Science 39:234-240.

Randall, J. E. 1967. Food habits of reef fishes of the West Indies. Pages 665-847 in Proceedings of the International Conference on Tropical Oceanography. University of Miami, Miami, Florida, USA.

Robertson, A. E., and R. K. Howard. 1978. Diel trophic interactions between vertically-migrating zooplankton and their fish predators in an eelgrass community. Marine Biology 48:207-213.

Roughgarden, J., S. Gaines, and H. Possingham. 1988. Recruitment dynamics in complex life cycles. Science 241: $1460-1466$.

Rumrill, S. S. 1990. Natural mortality of marine invertebrate larvae. Ophelia 32:163-198.

Rumrill, S. S., J. T. Pennington, and F.-S. Chia. 1985. Differential susceptibility of marine invertebrate larvae: laboratory predation of sand dollar, Dendraster excentricus (Eschscholtz), embryos and larvae by zoeae of the red crab, Cancer productus Randall. Journal of Experimental Marine Biology and Ecology 90:193-208.

Ruppert, E., and R. Fox. 1988. Seashore animals of the southeast. University of South Carolina Press, Columbia, South Carolina, USA.

Singarajah, K. V. 1969. Escape reactions of zooplankton: the avoidance of a pursuing siphon tube. Journal of Experimental Marine Biology and Ecology 3:172-178.

- 1975. Escape reactions of zooplankton: effects of light and turbulence. Journal of the Marine Biological Association of the United Kingdom 55:627-640.

Sterrer, W. 1986. Marine flora and fauna of Bermuda. John Wiley \& Sons, New York, New York, USA.

Stoner, D. S. 1990. Recruitment of a tropical colonial ascidian: relative importance of pre-settlement vs. post-settlement processes. Ecology 71:1682-1690.

Strathmann, R. R. 1974. The spread of sibling larvae of sedentary marine invertebrates. American Naturalist 108: $29-44$.

1980. Why does a larva swim so long? Paleobiology 6:373-376.

1985. Feeding and nonfeeding larval development and life-history evolution in marine invertebrates. Annual Review of Ecology and Systematics 16:339-361.

- 1986. What controls the type of larval development? Summary statement for the evolution session. Bulletin of Marine Science 39:616-622.

1993. Hypothesis on the origins of marine larvae. Annual Review of Ecology and Systematics 24:89-117. Strathmann, R. R., and M. F. Strathmann. 1982. The rela- 
tionship between adult size and brooding in marine invertebrates. American Naturalist 119:91-101.

Sutherland, J. P. 1981. The fouling community at Beaufort, North Carolina: a study in stability. American Naturalist 118:499-519.

Svane, I., and C. M. Young. 1989. The ecology and behaviour of ascidian larvae. Pages 45-90 in M. Barnes, editor. Oceanography and Marine Biology, an Annual Review 27.

Thorson, G. 1946. Reproduction and larval development of Danish marine bottom invertebrates. Meddeleser Kommissionen for Danmarks Fisheriog Havundersogelser, Serie: Plankton 4:1-523.

. 1950. Reproductive and larval ecology of marine bottom invertebrates. Biological Reviews 25:1-45.

Underwood, A. J. 1974. On models for reproductive strategies in marine benthic invertebrates. American Naturalist 108:874-878.

Van Alstyne, K. L., and V. J. Paul. 1992. Chemical and structural defenses in the sea fan Gorgonia ventalina: effects against generalist and specialist predators. Coral Reefs 11:155-159.

Van Alstyne, K. L., C. R. Wiley, and V. J. Paul. 1994. Antipredator defenses in tropical Pacific soft corals (Coelenterata: Alcyonacea). II. The relative importance of chemical and structural defenses in three species of Sinularia. Journal of Experimental Marine Biology and Ecology 178:17-34.

Van Alstyne, K. L., C. R. Wiley, V. J. Paul, and K. Meyer 1992. Antipredator defenses in tropical Pacific soft corals (Coelenterata: Alcyonacea). I. Sclerites as defense against generalist carnivorous fishes. Biological Bulletin 182:231240.

van Duyl, F. C., R. P. M. Bak, and J. Sybesma. 1981. The ecology of the tropical compound ascidian Trididemnum solidum. I. Reproductive strategy and larval behaviour. Marine Ecology Progress Series 6:35-42.

Vance, R. R. 1973. On reproductive strategies in marine benthic invertebrates. American Naturalist 107:339-352.

Westneat, M. W., and J. M. Resing. 1988. Predation on coral spawn by planktivorous fish. Coral Reefs 7:89-92.

Yamaguchi, M. 1973. Early life histories of coral-reef asteroids, with special reference to Acanthaster planci (L.). Pages 369-387 in O. A. Jones and R. Endean, editors. Biology and geology of coral reefs. Volume II. Biology 1. Academic Press, New York, New York, USA.

- 1974. Larval life span of the coral-reef asteroid Gomophinegy ptiaca, Gray. Micronesica 10:57-64.

Young, C. M. 1986. Direct observation of field swimming behavior in larvae of the colonial ascidian Ecteinascidia turbinata. Bulletin of Marine Science 39:279-289.

Young, C. M., and B. L. Bingham. 1987. Chemical defense and aposematic coloration in larvae of the ascidian Ecteinascidia turbinata. Marine Biology 96:539-544.

Young, C. M., and F.-S. Chia. 1987. Abundance and distribution of pelagic larvae as influenced by predation, behavior, and hydrographic factors. Pages 385-463 in C. Giese, J. S. Pearse, and V. B. Pearse, editors. Reproduction of marine invertebrates. Volume 9. Blackwell Scientific, Palo Alto, California and The Boxwood Press, Pacific Grove, California, USA.

Zaret, T. M., and W. C. Kerfoot. 1975. Fish predation on Bosmina longirostris: body-size selection versus visibility selection. Ecology 56:232-237.

Zea, S. 1987. Esponjas del Caribe Columbiano. Editorial Catologo Scientifica, Santa Marta, Columbia. 


\section{APPENDIX A}

Collection sites, depths, and seasons for benthic invertebrates and larval predators used in this investigation.

\begin{tabular}{|c|c|c|c|}
\hline Species & Collection site & Depth (m) & Season \\
\hline Caribbean sponges & & & \\
\hline $\begin{array}{l}\text { Callyspongia vaginalis } \\
\text { Cälyx podatypa } \\
\\
\text { Monanchora unguifera } \\
\text { Mycale laxissima } \\
\text { Niphates digitalis } \\
\text { Pseudoceratina crassa } \\
\text { Ptilocaulis spiculifera } \\
\text { Tedania ignis } \\
\text { Ulosa ruetzleri } \\
\text { Ectyoplasia ferox } \\
\text { Xestospongia muta }\end{array}$ & $\begin{array}{l}\text { Conch Reef, Pickles Reef, Florida } \\
\text { Little San Salvador, Bahamas } \\
\text { Conch Reef, Florida } \\
\text { Pickles Reef, Florida } \\
\text { Three Sisters Reef, Florida } \\
\text { Conch Reef, Pickles Reef, Florida } \\
\text { Three Sisters Reef, Florida } \\
\text { Chub Cay, Bahamas } \\
\text { Jewfish Creek, Key Largo, Florida } \\
\text { Conch Reef, Florida } \\
\text { Conch Reef, Florida } \\
\text { Conch Reef, Florida }\end{array}$ & $\begin{array}{r}2-30 \\
25-30 \\
25-30 \\
10-12 \\
3-6 \\
6-30 \\
5-6 \\
15-25 \\
1-2 \\
20-30 \\
20-30 \\
20-30\end{array}$ & $\begin{array}{l}\text { Oct 1991; Aug } 1993 \\
\text { Jul } 1992 \\
\text { Aug } 1992 \\
\text { Jul } 1993 \\
\text { Jul } 1993 \\
\text { Aug } 1992 ; \text { Jul } 1993 \\
\text { Jul 1993 } \\
\text { Jul } 1992 \\
\text { Aug } 1993 \\
\text { Aug } 1992 \\
\text { Aug } 1992 \\
\text { Aug } 1992\end{array}$ \\
\hline $\begin{array}{l}\text { Caribbean gorgonians } \\
\text { Briareum asbestinum-E } \\
\text { Briareum asbestinum-U } \\
\text { Eunicea mammosa } \\
\text { Eunicea tourneforti } \\
\text { Erythropodium caribaeorum } \\
\text { Plexaura flexuosa } \\
\text { Plexaurella dichotoma } \\
\text { Pseudoplexaura porosa-A } \\
\text { Pseudoplexaura porosa-B }\end{array}$ & $\begin{array}{l}\text { Three Sisters Reef, Florida } \\
\text { Three Sisters Reef, Florida } \\
\text { Pickles Reef, Florida } \\
\text { Pickles Reef, Florida } \\
\text { Three Sisters Reef, Florida } \\
\text { Pickles Reef, Florida } \\
\text { Pickles Reef, Florida } \\
\text { Three Sisters Reef, Florida } \\
\text { Three Sisters Reef, Florida }\end{array}$ & $\begin{array}{l}3-6 \\
3-6 \\
3-4 \\
3-4 \\
3-6 \\
3-4 \\
3-4 \\
3-6 \\
3-6\end{array}$ & $\begin{array}{l}\text { Jul } 1993 \\
\text { Jul } 1993 \\
\text { Jun 1992, } 1993 \\
\text { Aug 1992,1993 } \\
\text { Aug 1993 } \\
\text { Aug 1993 } \\
\text { Aug 1993 } \\
\text { Jul 1993 } \\
\text { Aug 1993 }\end{array}$ \\
\hline $\begin{array}{l}\text { Caribbean corals } \\
\text { Agaricia agaricites } \\
\text { Porites astreoides } \\
\text { Siderastrea radians }\end{array}$ & $\begin{array}{l}\text { Pickles Reef, Florida } \\
\text { Pickles Reef, Florida } \\
\text { Pickles Reef, Florida }\end{array}$ & $\begin{array}{l}5 \\
5 \\
2-4\end{array}$ & $\begin{array}{l}\text { Jul } 1993 \\
\text { Jul } 1993 \\
\text { Aug } 1993\end{array}$ \\
\hline $\begin{array}{l}\text { North Carolina sponges } \\
\text { Adocia tubifera } \\
\text { Ulosa ruetzleri }\end{array}$ & $\begin{array}{l}\text { Radio Island Jetty, Beaufort, North Carolina } \\
\text { rock ledge, Wrightsville Beach, NC }\end{array}$ & $\begin{array}{c}2-5 \\
17-19\end{array}$ & $\begin{array}{l}\text { Jun } 1991,1992 \\
\text { Sep } 1992\end{array}$ \\
\hline $\begin{array}{l}\text { North Carolina hydroids } \\
\text { Eudendrium carneum } \\
\text { Corydendrium parasiticum }\end{array}$ & $\begin{array}{l}\text { Radio Island Jetty, Beaufort, North Carolina } \\
\text { rock ledge, Wrightsville Beach, North Carolina }\end{array}$ & $\begin{array}{c}2-5 \\
17-19\end{array}$ & $\begin{array}{l}\text { Jun, Sep } 1991 \\
\text { Jul } 1991\end{array}$ \\
\hline $\begin{array}{l}\text { North Carolina bryozoan } \\
\text { Bugula neritina }\end{array}$ & Radio Island Jetty, Beaufort, North Carolina & $2-5$ & Jul 1991, Jun 1992 \\
\hline $\begin{array}{l}\text { North Carolina ascidians } \\
\text { Aplidium constellatum } \\
\text { Aplidium stellatum } \\
\text { Eudistoma carolinensis }\end{array}$ & $\begin{array}{l}\text { Radio Island Jetty, Beaufort, North Carolina } \\
\text { Radio Island Jetty, Beaufort, North Carolina } \\
\text { Radio Island Jetty, Beaufort, North Carolina }\end{array}$ & $\begin{array}{l}2-5 \\
2-5 \\
2-5\end{array}$ & $\begin{array}{l}\text { Jun, Jul } 1991 \\
\text { Jun, Jul } 1991 \\
\text { Aug } 1991\end{array}$ \\
\hline $\begin{array}{l}\text { Larval predators } \\
\text { Thalassoma bifasciatum } \\
\text { Stegastes partitus } \\
\text { Lagodon rhomboides } \\
\text { Monocanthus ciliatus }\end{array}$ & $\begin{array}{l}\text { various reefs in Bahamas, Pickles Reef, Florida } \\
\text { Pickles Reef, Florida } \\
\text { seagrass beds, Morehead City, North Carolina } \\
\text { seagrass beds, Morehead City, North Carolina }\end{array}$ & $\begin{array}{l}2-10 \\
2-10 \\
1 \\
1\end{array}$ & $\begin{array}{l}\text { collected as needed } \\
\text { collected as needed } \\
\text { collected as needed } \\
\text { collected as needed }\end{array}$ \\
\hline
\end{tabular}




\section{APPENDIX B}

\section{Larval Collection Methods}

\section{Sponges}

A) Adocia tubifera, Callyspongia vaginalis, Calyx podatypa, Monanchora unguifera, Niphates digitalis, Ptilocaulis spiculifera, Ulosa ruetzleri.-In the field, reproductive colonies were identified by having round or oval-shaped bodies embedded in the tissue. Portions of reproductive colonies were bagged underwater and transported to the laboratory. Released larvae were concentrated by pouring water from the bags through a $100-\mu \mathrm{m}$ Nitex sieve. Sponges were then dissected to expose additional brooding chambers, and larvae that swam free were collected.

B) Reproductive colonies identified as above, but: (1) Mycale laxissima adults were dissected in the field while scuba diving, and released larvae were collected with a pipet, (2) Pseudoceratina crassa adults were placed in larval traps in the field, (3) Tedania ignis larvae were collected in situ by pulling a plankton net through the channel of a mangrove swamp.

C) Gelatinous masses containing embryos and larvae of Ectyoplasia ferox and Xestospongia muta were collected from sponge surfaces in the field.

\section{Gorgonians}

A) Briareum asbestinum.-Encrusting and upright forms (see Brazeau and Harvell 1994 for a genetic description of these two sister species).-Portion of colonies found with developing embryos and larvae on the colony's surface were bagged underwater and returned to the laboratory.

B) For all other gorgonians, gravid females were identified by the presence of spherical bodies in their cross-sectioned branches. (1) For the internal brooder Eunicea mammosa branches from 15 to 20 colonies were sectioned into $0.5-1.0$ $\mathrm{cm}$ pieces in the laboratory. When these sections were submerged in seawater, we collected the fully developed planulae that swam free. (2) Eggs and embryos of the broadcast spawning gorgonians Pseudoplexaura porosa-A and-B were collected as these animals spawned just after sunset in the field. A mesh net $(200 \mu \mathrm{m})$ held over 6-8 spawning colonies cap- tured eggs as they floated toward the surface. Fertilization likely occurred as we swam between animals. The distinction between A and B was based on differences (A vs. B) in spawning times (July vs. August), larval color (white vs. tan), and palatability (unpalatable vs. palatable, Fig. 4). (3) For Erythropodium caribaeorum, Eunicea tourneforti, Plexaura flexuosa, and Plexaurella dichotoma, we placed portions of gravid female and male colonies together in 300-L tanks. The seawater was recirculated with small submersible pumps and changed 2-3 times daily. We collected colonies 1-2 d before their predicted spawning dates. Spawning always occurred 1-3 $\mathrm{h}$ after sunset.

\section{Hard corals}

Agaricia agaricites, Porites divaricata, and Siderastrea radians.-In the laboratory, coral colonies approaching a peak in larval spawning were held collectively in a shallow water table or individually in 1-L plastic buckets. Larvae were released only at night and were collected the following morning. Agaricia and Porites larvae were provided by Gerry Wellington (University of Houston).

\section{Hydroids}

Corydendrium parasiticum and Eudendrium carneum.--In the field, reproductive colonies were identified by having external clusters of larval brooding sacs. In the laboratory, hydroid colonies were placed in shallow flow-through water tables for 2-3 d. Each day at midmorning, the crawl-away larvae were collected from the bottom of the water tables.

\section{Bryozoans and ascidians}

Bugula neritina, Aplidium constellatum, Aplidium stellatum, Eudistoma carolinensis.-In the field, bryozoan (B. neritina) colonies with obvious larva-containing ovicells were collected. In the laboratory, we exposed bryozoan and ascidian colonies to bright light after keeping them in the dark overnight. This light shock stimulated these invertebrate to release larvae that we collected with a pipet. 
APPENDIX C

Some reproductive and physical features of invertebrates used in this investigation.

\begin{tabular}{|c|c|c|c|c|}
\hline Species & $\begin{array}{l}\text { Repro- } \\
\text { ductive } \\
\text { mode } \dagger\end{array}$ & $\begin{array}{l}\text { Diel } \\
\text { timing of } \\
\text { larval or } \\
\text { gamete } \\
\text { release } \ddagger\end{array}$ & $\begin{array}{l}\text { Larval } \\
\text { color }\end{array}$ & $\begin{array}{c}\text { Larval } \\
\text { size§ } \\
(\mathrm{mm})\end{array}$ \\
\hline \multicolumn{5}{|l|}{ Caribbean sponges } \\
\hline $\begin{array}{l}\text { Callyspongia vaginalis } \\
\text { Calyx podatypa } \\
\text { Monanchora unguifera } \\
\text { Mycale laxissima } \\
\text { Niphates digitalis } \\
\text { Pseudoceratina crassa } \\
\text { Ptilocaulis spiculifera } \\
\text { Tedania ignis } \\
\text { Ulosa ruetzleri } \\
\text { Ectyoplasia ferox } \\
\text { Xestospongia muta }\end{array}$ & $\begin{array}{l}\text { B } \\
\text { B } \\
\text { B } \\
\text { B } \\
\text { B } \\
\text { B } \\
\text { B } \\
\text { B } \\
\text { B } \\
\text { EM } \\
\text { EM }\end{array}$ & $\begin{array}{l}\text { day-f } \\
\text { unknown } \\
\text { unknown } \\
\text { day-f } \\
\text { day-f } \\
\text { midday-f } \\
\text { unknown } \\
\text { day-f } \\
\text { unknown } \\
\text { NA } \\
\text { NA }\end{array}$ & $\begin{array}{l}\text { light gray } \\
\text { yellow or white } \\
\text { red } \\
\text { red } \\
\text { gray } \\
\text { yellow } \\
\text { red } \\
\text { red } \\
\text { orange } \\
\text { orange } \\
\text { white }\end{array}$ & $\begin{array}{l}0.8-1.4 \\
6-8 \\
1.5-2.0 \\
2.0-2.5 \\
1.5-2.0 \\
1.5-2.0 \\
1.5-2.0 \\
0.3-0.4 \\
1.5-2.0 \\
0.1-0.2 \\
0.1-0.2\end{array}$ \\
\hline $\begin{array}{l}\text { Caribbean gorgonians } \\
\text { Briareum asbestinum-E } \\
\text { Briareum asbestinum-U } \\
\text { Eunicea mammosa } \\
\text { Eunicea tourneforti } \\
\text { Erythropodium caribaeorum } \\
\text { Plexaura flexuosa } \\
\text { Plexaurella dichotoma } \\
\text { Pseudoplexaura porosa-A } \\
\text { Pseudoplexaura porosa-B }\end{array}$ & $\begin{array}{l}\text { SB } \\
\text { SB } \\
\text { B } \\
\text { SBS } \\
\text { SBS } \\
\text { SBS } \\
\text { SBS } \\
\text { SBS } \\
\text { SBS }\end{array}$ & $\begin{array}{l}\text { NA } \\
\text { NA } \\
\text { unknown } \\
\text { night-1 } \\
\text { night-1 } \\
\text { night-1 } \\
\text { night-1 } \\
\text { night-f } \\
\text { night-f }\end{array}$ & $\begin{array}{l}\text { orange } \\
\text { orange } \\
\text { white } \\
\text { pink } \\
\text { gray } \\
\text { pink } \\
\text { tan } \\
\text { white } \\
\text { tan }\end{array}$ & $\begin{array}{l}3-4 \\
3-4 \\
2-3 \\
1.5-2.0 \\
2.0-2.5 \\
1.5-2.0 \\
1.5-2.0 \\
1.5-2.0 \\
1.5-2.0\end{array}$ \\
\hline $\begin{array}{l}\text { Caribbean corals } \\
\text { Agaricia agaricites } \\
\text { Porites astreoides } \\
\text { Siderastrea radians }\end{array}$ & $\begin{array}{l}\mathrm{B} \\
\mathrm{B} \\
\mathrm{B}\end{array}$ & $\begin{array}{l}\text { night-f } \\
\text { night-1 } \\
\text { night-1 }\end{array}$ & $\begin{array}{l}\text { brown } \\
\text { brown } \\
\text { white }\end{array}$ & $\begin{array}{l}1.5-2.5 \\
0.5-1.0 \\
0.5-1.0\end{array}$ \\
\hline $\begin{array}{l}\text { North Carolina sponges } \\
\text { Adocia tubifera } \\
\text { Ulosa ruetzleri }\end{array}$ & $\begin{array}{l}\mathrm{B} \\
\mathrm{B}\end{array}$ & $\begin{array}{l}\text { unknown } \\
\text { unknown }\end{array}$ & $\begin{array}{l}\text { lavender } \\
\text { orange }\end{array}$ & $\begin{array}{l}0.8-1.2 \\
1.5-2.0\end{array}$ \\
\hline $\begin{array}{l}\text { North Carolina bryozoan } \\
\text { Bugula neritina }\end{array}$ & B & day-1 & brown & $0.2-0.5$ \\
\hline $\begin{array}{l}\text { North Carolina hydroids } \\
\text { Eudendrium carneum } \\
\text { Corydendrium parasiticum }\end{array}$ & $\begin{array}{l}\mathrm{B} \\
\mathrm{B}\end{array}$ & $\begin{array}{l}\text { day-1 } \\
\text { day-1 }\end{array}$ & $\begin{array}{l}\text { orange } \\
\text { orange }\end{array}$ & $\begin{array}{l}0.8-1.0 \\
0.8-1.0\end{array}$ \\
\hline $\begin{array}{l}\text { North Carolina ascidians } \\
\text { Aplidium constellatum } \\
\text { Aplidium stellatum } \\
\text { Eudistoma carolinensis }\end{array}$ & $\begin{array}{l}\text { B } \\
\text { B } \\
\text { B }\end{array}$ & $\begin{array}{l}\text { day-1 } \\
\text { day-1 } \\
\text { day-1 }\end{array}$ & $\begin{array}{l}\text { light orange } \\
\text { light yellow } \\
\text { transparent }\end{array}$ & $\begin{array}{l}3-4 \\
3-4 \\
2-3\end{array}$ \\
\hline
\end{tabular}

$\dagger \mathrm{B}=$ brooder (none direct developers); $\mathrm{EM}=$ larvae develop within gelatinous egg masses; $\mathrm{SB}=$ surface brooder; SBS = synchronous broadcast spawner.

$\$$ These data are based on field (f) and laboratory (l) observations; NA $=$ not applicable for surface-brooding species for which larvae remain on the surface of the adult colonies for 3-5 $\mathrm{d}$ or species that embed larvae in gelatinous masses where larvae develop. $\S$ Measurement of the largest larval dimension. 